\title{
Mazdeans and Christians Facing the End of the World Circulations and Exchanges of Concepts
}

\author{
ANTONIO PANAINO \\ University of Bologna, Italy
}

\begin{abstract}
This contribution offers a conspectus of the parallel treatment of some eschatological subjects in the comparative framework of Mazdean and Christian sources. Although some impact of the Judeo-Christian tradition on Iranian apocalypticism has been fittingly detected in previous studies, the author insists on evidence showing a sort of circular exchange between Christians and Mazdeans, where, for instance, chiliasm presents some Iranian (and not only Babylonian) resonances, while the well-known Zoroastrian doctrine of universal mercy and of the apokatastasis shows impressive correspondences with the Origenian doctrines. What distinguishes the Iranian framework is the fact that millenarianism, apocalypse and apokatastasis did not directly contrast, as it happened in the Christian milieu. These Christian doctrines played a certain influence in Sasanian Iran, although their diffusion and acceptance was probably slow and progressive, and became dominant among Zoroastrians only after the fall of the Sasanian period, when the Mazdean Church was no longer the pillar of the state and the social and legal order. The diffusion of the doctrine of universal mercy was a later acquisition, as shown from the evidence that earlier Mazdean doctrines did not assume a complete salvation for the wicked but prescribed a harsh and eternal punishment for them. Furthermore, the author focuses on his own research on these subjects and summarises some results concerning a new and original presentation of the Mazdean concept of evil as a manifestation of suffering, comparable to a state of mental 'sickness.'
\end{abstract}

KEYWORDS eschatology, millenarianism, Mazdeism, origenism, apokatastasis, evil, psychology

\section{Introduction}

In the present contribution I would like to develop some considerations which began in the last years about the complexity of the relations between Mazdeans and Christians in late Antiquity. ${ }^{1}$ I would also like to insist on the importance of this subject because it gives us the

1 In this study I have taken the opportunity to resume some of my previous research, which I have developed with a large and detailed bibliography in other publications, and to anticipate forthcoming results. The 
opportunity to focus on the multicultural dimension of the pre-Islamic Iranian world and its richness beyond the traditional borders of Christian and Medieval Studies, which sometimes forget the relevant role played by the Ërānšahr on the neighbouring countries; furthermore, it is important that a community of scholars as ours might share its views about these problems, avoiding the risks of a certain isolation that could confine our research interests to a sort of esoteric limbo. And this is particularly important now, when many young scholars have offered deep and seminal studies on such an intercultural subject. ${ }^{2}$ Furthermore, I will try to focus on the fact that the Iranian area has played a remarkable role in the transmission, ramification and evolution of some fundamental theological ideas which became current in late Antiquity and the early Middle Ages, and will argue that this ambiance strongly influenced an intellectual debate that was much more universal and cross-cultural than is generally presumed.

\section{The Millenaristic Problem}

I recently had the chance to observe (Panaino 2016) ${ }^{3}$ that in the Wizidagiha $\bar{\imath}$ Zādspram (The Selections of Zādspram), chapter XXVIII, 2, the symbolic number attributed to Ahreman's invasion of the gètig world directly evokes that of the Beast in John's Gospel, chapter XIII, 17-18. The figure prevailing in the Christian framework, as is well known, was 666, while the Mazdean one is 6666. The relations and the connections between these two numbers are evident not only because of their patent similarity, but also considering the millenarian arguments adopted by Irenaeus of Lyon in order to explain the cosmic meaning of 666, which, mutatis mutandis, result in basically the same endorsed by Zādspram some centuries later. ${ }^{4}$ Actually, both theologians considered the number six as the basic figure indicating the complete number of millennia covering the history of the world and its decimal multiple, 60 or 600 , as respectively referring to a series of centuries $(60 \times 100=6000)$ or of decades $(600 \times 10$ $=6000$ ). In any case, both authors were consciously operating in the patent framework of a chiliastic speculation, emphasizing the full completion of a round cycle of six thousand years in which the fight against evil should take place. This common emphasis on six millennia is relevant per se because it shows how Judeo-Christian chiliasm crossed the border and, in turn, was influenced by Iranian millenarianism. ${ }^{5}$ It is true that the Zoroastrian cycle in its complete duration was of 12,000 years (or of $9,000+3,000$ ), divided in two distinct sub-periods of 6,000 each, one mēnōg, the latter gētig, ${ }^{6}$ while Judeo-Christian chiliasm insisted on the role of an additional millennium, the seventh, to be attached after the first six millennia in order

reader will forgive these self-quotations, but I desired to avoid any heavy repetition of a full apparatus of sources and notes which have already been offered elsewhere. Some of these previous works were written in Italian, and it is possible that they have escaped and will escape the attention of some scholars. Thus, I believe that a new up-to-date version of their contents could be of a certain utility. I take also the opportunity to thank Dr. Samra Azarnouche (EPHE, Paris) for her kindness in sharing some opinions about the problems I have discussed in the present work, and to Prof. Dr. Kianoosh Rezania (Ruhr-Universität Bochum) for his invitation to take part in a seminal conference dedicated to the intercultural problems I have tried to analyse in this study.

$2 \quad$ See most recently Panaino (2004b); Walker (2006); Minov (2013); Payne (2015).

3 On the Wizìdagihā $\bar{\imath}$ Zādspram, ch. XXVIII, 2, see Gignoux and Tafazzoli (1993, 92-93, 255-56, Pahlavi text).

$4 \quad$ All the details are collected in my study quoted above; see also Panaino (2017g).

$5 \quad$ On this subject, see Panaino (2017g).

6 An analytic description of the facts is given in Panaino (2017g). Sometimes only 9,000 years are mentioned because the first period before the meeting and the pact between Ohrmazd and Ahreman is not considered. 
to represent a paradisiacal phase accessible only to a limited group of 'elects' before the final judgment. But the period of the battle, the fight against evil in the world, in both cases remains inscribed into a frame of 6,000 years, and this similarity probably did not escape ancient observers. We must also recall that the Judeo-Christian background of chiliasm has traditionally been connected (following a thesis suggested by Cumont 1931; see also Panaino 2017g) with the Babylonian astral tradition, in particular with the importance attributed in Mesopotamia to the power of the planets (including, of course, the two luminaries, i.e. the sun and the moon). But the interest for the representation of a millenarian period working as a Great Cosmic Year, whose borders represent two extreme sides, the beginning and the end of the earthly creation and, with it, of the human struggle, remains strongly rooted in the Iranian tradition. We must insist, following Sasha Stern (2007, 103-23 and in particular 118n95-96), ${ }^{7}$ on the evidence that the Iranian world, and not the Mesopotamian or the Greek one, was the first to elaborate a deep speculation about the concept—or, better, category-of 'time' according to a sort of pre-philosophical determination. Thus, this happened in spite of the fact that the Babylonian culture was able to elaborate complex mathematical parameters for the periodical numeration of the diurnal motion of the visible astral bodies and improved intercalary systems for a more precise synchronism with seasonal phenomena. In other words, the interest for the divine prerogatives of time in its para-philosophical relation with the limited, historical dimension, and contrariwise the dialectics between eternity and temporal limits, were an Iranian intellectual challenge. The origins of these speculations can be identified in the Avestan corpus (Yt. 13, 53-58; see Kellens 2000, 2009), where we find scattered but coherent and precise references to the existence of millenarian periods, framed in the dimension of limited time, where the astral bodies started to move after a period of immobility (Panaino $2017 \mathrm{~g}$ ). The latter point shows that the idea of a direct cosmological distinction between a phase of immobility and another one of motion, connected with the mēnōg and gētig ontological articulations of reality, was also already fixed in its main lines in the Achaemenid period.

The relation between eternal, unlimited or borderless time and its subordinate dimension, having borders, also involves the quality of divine actions, starting with the theological qualification of the supreme divinity. Ohrmazd, in fact, not only has the power to entrap Ahreman in a limited space-time dimension, fighting against him in a position of absolute superiority. ${ }^{8}$ Actually, the supreme god also disposes of the power to remain in an eternal state, outside of mixed creation, entering into it only when strictly necessary, as just at the end of the cosmic battle for the celebration of the sacrifice of the world's renovation. Some Young Avestan passages in the Mihr (stanza 55) and Tištar Yašts (stanza 11) clearly state that the yazatas, or at least some of them (like MiӨra and Tištrya), can enter and exit limited time, and that they have the privilege to enter and exit the two different qualitative temporal dimensions while all the negative forces are blocked inside creation and its space-time limits. ${ }^{9}$ This 'qualitative' difference-and I insist on the term qualitative - has a certain number of theological and

$7 \quad$ Von Orelli $(1871,109-10)$ anticipated some ideas later developed by Stern.

8 Ohrmazd is equipped with forces possessing a double nature, one mēnōg, the latter gètig, while Ahreman has at his disposal only mēnōg creatures, because he was in a state of complete stupefaction (stardih) during the second cycle of 3,000 years of the mennog period. This double articulation of the world, which practically corresponds to a double level of creation, can be compared with some ideas later developed by the Jewish Platonist Philo of Alexandria, as well as by Origen and Gregory of Nyssa, as rightly remarked by Ramelli (Ramelli 2017, 383-84).

9 For a detailed textual analysis of these sources and their interpretation, see Kellens (2000), Kellens (2009), Panaino (2017g). Kellens' philological revision of the text and his emendations are indispensable in order to properly understand the real meaning of these passages. 
para-philosophical implications, because it shows that the basic pillars of later Mazdean cosmology were fixed in the period of composition of Young Avestan sources (Panaino 2017g), and that the influence of these general categories on close cultural traditions can be easily supposed, and in some cases reasonably admitted. Thus, while we have no reason to dismiss the traditional assumption that it was the Mesopotamian world that exported planetary millenarianism with its pattern of the seven millennia, this doctrine was not isolated, and its diffusion was not in contrast to the observation that the seven planetary bodies all move along a path of twelve zodiacal signs, and that in a millenarian speculation the relation between seven, nine or twelve millennia represent only different, but not antagonist, schemes based on the same idea that a limited time, measurable using the motion of certain astral cycles, determines the duration of the world and that of the fight between good and evil forces.

Although I do not want to insist here on the problems connected with the interrelation of millenarianism in the Judeo-Christian and Mazdean worlds, I must emphasize that at least some Zoroastrian theologians were particularly worried about the problem of the stability of limited time. If the arms of the macrocosmic clock, the visible cosmos, mark the progress of the millennia and announce the coming of the last moment, a strong interest of Ahreman's would be blocking and delaying its regular course, so that the expected end, the final fight, with the inevitable destruction of evil and even of hell, would be untimely delayed. This problem has been discussed only superficially in scholarly literature, although we find in the Denkkard some peculiar passages in which the Druj expressly tries to block the motion of the sun in coincidence with the visible manifestations of the three Sōšāns. ${ }^{10}$ This complex doctrine, the astronomical background of which cannot be investigated here, demonstrates that the regular course of the sun, and of limited time, must be protected against the actions of demoniac forces, which try to postpone or even to delay the end of limited time, also on the heavenly level. The expansion and dilatation of time is actually a daēvic event, which prolongs the presence of evil in creation, and it is for this reason that the regular course of time must be shielded in its sequence till its total completion. In my opinion, this need was well focused on already in Avestan times, because it is in the Mazdean liturgies that we find a recurrent concern for the worship offered to the different portions of time: days, parts of the days, months, different phases of the month and of its lunations, the thirty single days, the seasons and seasonal festivals, individual years and, implicitly, the sequences of years (Panaino 2017b). This insistence, quasi obsessive, shows that the cosmic order, starting with regular time sequences, must be supported and protected, and that the ritual performances contribute to its stability against any evil attempt of temporal disarticulation. The Mazdean liturgical calendar and its performative celebration through the five daily ritual sessions, or $g \bar{a} h^{11}$, was per se a strong weapon against the disruptive force of Ahreman, and it probably influenced other cultural traditions, such as the Islamic one, which in any case adopted a similar ritual sequence of daily prayers. ${ }^{12}$ Furthermore, we must observe that the Mazdean liturgy, with its process of the installation of the incoming ritual college, to which the duty of performing the new ceremony must be transferred, implies a concatenation of rituals (Panaino 2017d) from one priestly college to another, as in an uninterrupted sequence to cover (and

10 The most pertinent texts are attested in Dēnkard III, 160 and 407; they are edited, translated and discussed in Panaino (2018) with a large bibliography on the subject.

11 These are: Hāwan (morning), Rapihwin (afternoon), Uzērin (evening), Ēbsrūsrim (sunset to midnight) and Ušahin (midnight to dawn). See MacKenzie (1971, 143). For the liturgical implication of these five ceremonies, see Panaino (Forthcoming).

12 On this sensible matter Shaked (2002) very sharply wrote: "The imposition of five daily prayers in Islam has been shown by Goldziher (1900, 132-33) to be a development due to Zoroastrian influence." 
protect) the whole time of the world. This was probably the deepest concept underpinning the ideology of the liturgy, to be considered as a unique continuous celebration, through which the pillars of the world were maintained and protected against the disruptive action of Ahreman and his army.

\section{Time and Salvation: Eternal or Limited Hell?}

Thus, the end of time represents a conceptual subject because it opens the way to a transumanatio and transfiguratio of humanity, ${ }^{13}$ creating a new state of transcendental life in which the dualism represented by the antagonistic presence of evil will be completely eradicated. But this final status implies consequences that we can find with sufficient clarity in later Pahlavi sources. In particular, I am interested in the subject of the total elimination of hell and of the complete remission of sins to all persons previously condemned to the harshest punishment: we can label this process as a kind of apokatastasis, because with its clear idea of a complete and definitive restoration of the cosmic and divine order, as was the case before the irruption of evil, this doctrine involves a series of comparanda that can be directly observed, mutatis mutandis, in the Christian world, particularly in the theology of Clemens of Alexandria and, most significantly, of Origen (Panaino 2017c). ${ }^{14}$ The first of these Christian theologians started to suggest, although in a prudent way, that it would be possible to imagine universal salvation for all intelligent creatures (Stromata [i.e. "Miscellanies"] VII, 2.12.2-3.13.1). ${ }^{15}$ In this way, all punishments in the afterlife would correspond to a compulsory purification of the soul more than to simple retribution. It is in this framework that the 'restoration' assumes its full relevance, and that the future doctrine of Christian purgatory finds its starting point. The following Christian formulation of the apokatastasis, as developed by Origen, is per se a problem not only because it was condemned by Justinian as heretical, but also because it represents a tantalizing subject in modern theology, where it has been reformulated with many prudent nuances and some caveats; for instance, Hans Urs von Balthasar's Kleiner Diskurs über die Hölle (A Little Discourse about the Hell; Balthasar 1987) was followed (within the same booklet in the edition of 1999; Balthasar 1999) by another pamphlet of the same author programmatically entitled Apokatastasis. This study was the fruit of a conference delivered in 1988 in Trier and published in the same year (Balthasar 1988).

Prudently, we must remark that it is not very simple to distinguish what was stated by Origen himself and what has been attributed to him by his supporters or even by his enemies, so that sometimes doctrines that can be seen as 'extreme' belong to a long tradition of struggles and polemics. Looking at these problems from the perspective of the Iranian late Antique reception, this cautious distinction, although important, is less significant because even the

13 On the concept of transfiguration in Pahlavi sources, see Shaked (1970).

14 Only during the final revision of this article did I have access to the article of Ramelli (2017), who on parallel lines investigates some aspect of the Iranian doctrine of the Frašgird, the final renovation, in connection with the Christian apokatastasis.

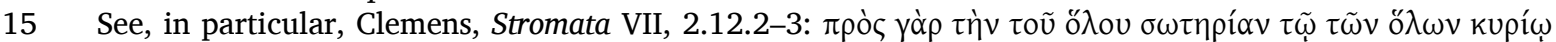

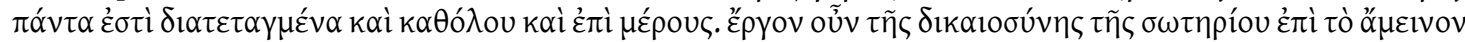

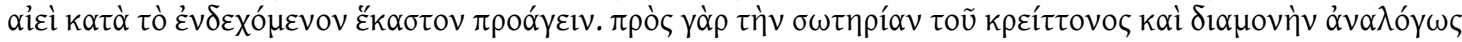

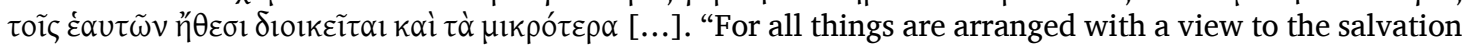
of the cosmos by the Lord of the universe, both generally and particularly. It is then the function of the righteousness of salvation to improve everything as far as practicable. For even minor matters are arranged with a view to the salvation of that which is better, and for an abode suitable for people's character [...]." For the Greek text see Früchtel, Stählin, and Treu (1979), translation according to Wilson (Clemens, n.d., 526). 
distortions had their weight in the Eastern areas and played their most seminal role. In any case, we will try to reflect on the impact of the tradition(s) attributed to Origen and whether they were true or (partially) false-although in some cases this influence produced very significant developments, as in the theory, attributed to Origen, of the final conversion of the Devil. I want to underline the intrinsic difficulty of this matter because the subject is not neutral, and it involves a lot of unresolved confessional and theological polemics which, of course, do not concern my approach but must be considered in the general context. In addition, it is interesting that the Iranian side of the doctrine of the apokatastasis, in its relation to the Christian Origenian tradition, presents us with a number of thrilling items. These 'Oriental reflexes' have generally been superseded in the scholarly framework, while contrariwise they confirm the importance of the Iranian world with regard to the eschatological debate of late Antiquity, a subject that-, with few exceptions ${ }^{16}$ - escapes the conspectus of the specialists of ancient theology and philosophy. We must also remark that in Zoroastrian Iran, the doctrine of the apokatastasis did not interfere with the earlier millenarian perspective, so that chiliasm and apokatastasis were not opposed at all ${ }^{17}$-in contrast to the Christian framework. ${ }^{18}$

But let us begin by following the historical sequence of events and related ideas. I have already noted that the very optimistic doctrine concerning the complete liberation of humanity and its admission to the beatification in the paradise of Ohrmazd does not represent the earliest Zoroastrian position, but that this was the result of a long internal debate that developed within the Mazdean community along the course of its history. Originally, as stated in Y. 46, 11, hell (drūjō dəmānēe) was "forever" (yauuōi vīspāi; see Kellens and Pirart 1988, $1: 161) .{ }^{19}$ If the Avestan sources do not show any particularly generous solution, we can doubt

16 The history of the discussion concerning the relations between Zoroastrianism and Christianity is a sensitive matter. It was part of the legacy left by the Religionsgeschichtliche Schule, whose Pro-Iranian excesses have been strongly criticized. Although some problems did in fact exist, we must remark that the debate was not only limited to the scholarly frame. On the contrary, it was strongly 'poisoned' by some anti-Semitic attempts to show the non-Jewish origin of Christ and Christianity (see in particular the materials collected by Heschel 2008, 26-66). On the other hand, the possibility that a certain exchange between Judaism, Christianity and Zoroastrianism could have taken place, for instance in the case of the idea of time, was considered by Sasse (1933, 197-98, 207) and developed by Cullman (e.g., 1962, 56, 61; but see also Barr 1962; see also Schaeder 1930). Recently, the relevance of the Jewish and Christian impact on Zoroastrian Iran has been shown by scholars like Gignoux $(1988,1968,1990,1999)$ and Cereti $(1995 b, 11-27,1995 c$, 1995a, 1996), who counter the thesis that Zoroastrian eschatology presents only the developments of a substantial early Iranian background. For a model suggesting the circulation of ideas and influences instead of unilateral influence in one way or the other, see Panaino (2016), Panaino (2017c), Panaino (2017g). A very recent study on the subject is offered by Hintze (2019). For revision of the problem of the apocalyptic in the Parthian framework, see Frenschkowsi (2004). For a certain Iranian influence on other religious traditions, see also Hultgård (2000), Kuehn (2014). On some related subjects concerning the afterlife, see also Tardieu (1985), and Panaino (2008).

17 For instance, according to chapter LIV, 6 of the Ardā Wìrāz Nāmag (Gignoux 1988, 100-101, 191), it is clear that the souls of the wicked are waiting for the end of the cosmic year in order to be released, although they suffer the spiritual quality of the punishment (Gignoux 1968, 239-41). In fact, for the sinner who is left alone in the darkness, every day is like the whole cosmic period of 9,000 years attributed to the fight between Ohrmazd and Ahreman. See again Ramelli (2017, 371).

18 On this aspect see Ramelli (2017), who started to investigate the possibility of this comparison.

19 Ramelli $(2017,366)$ does not recognize this fact, and in her article assumes that the earlier Avestan Mazdean doctrine was quite unclear on this subject. The same scholar $(2017,369)$ quotes the fact that

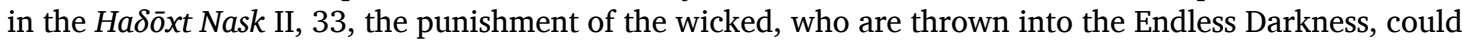
be interpreted, following an explanation suggested by Shaki (1986), as eternal, although the critical treatment of this source is very superficial. On this aspect, and in particular on the Avestan expression anarratəmah- (Pahl. asar tārīgìh, unlimited darkness), see Piras (2000, 67, 72, 120-21), with a wide conspectus

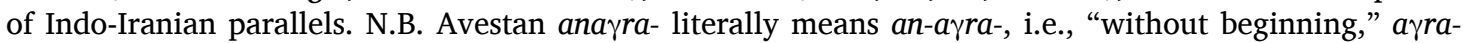
meaning as a neuter substantive "beginning, top," as adjective "first, foremost" (Bartholomae 1904, 49, 114-15), exactly like Vedic ágra-, n., "beginning" and "foremost, anterior, first." For this reason, it may 
that, even in the early Sasanian period, a priest such as Kirdīr would have supported this kind of tolerant perspective for sinners in the afterlife. I strongly doubt that a society such as the Sasanian one, at least in its first centuries, would have favoured such a 'liberal' doctrine concerning the future life, in particular when the same Mazdean priests were strongly in charge of secular and legal activities as judges, with the specific duty of prosecuting private and public crimes, religious infractions and heretical positions. In general, theology and political power can be dreadful sisters, and they usually impose narrow paths; I do not think that the working hypothesis that a church in charge of the law and in a frame of quasi-absolute authority was not in the favourable position to elaborate a very optimistic perspective regarding the postmortem is prejudiced. Tolerance was possible, but normally as the result of complex political negotiations, as was the case with the progressive respect attributed to some religious minorities in Iran. ${ }^{20}$ The theological idea that the final defeat of Ahreman will imply divine mercy for the whole of humanity with the total elimination of hell was very revolutionary and not established in a single night of particular generosity. Another external source demonstrating the Old Iranian background of the Mazdean belief in eternal punishment against people who denied the existence of the kingdom of light comes from the recently published Manichaean Kephalaion 341 of the Chester Beatty Library, ${ }^{21}$ which attributes to Zoroaster this severe doctrine in a framework clearly referring to other Mazdean traditions. Although this is a Manichaean source, it does not contain any a priori criticism against Zoroastrianism but describes the idea of eternal punishment as current in the Mazdean framework of late Antiquity. ${ }^{22}$ Thus, there are good reasons to presume that it reflected a current Zoroastrian opinion and not a distortion.

From a historical and political point of view, the radical assumption of final divine mercy represented a decision definitively established in a period of distress and defeat, probably officially canonized only after the Islamic conquest. In that phase, many Zoroastrians actually abandoned their ancestral religion, so that the Mazdean Church felt it necessary to enforce

also be translated as "infinite," but its basic semantic value does not involve strictly temporal implications; it refers to a spatial dimension, and in fact its adjectival use concerns light or darkness, or again the lights of the heaven. Furthermore, on p. 378 of her study, Ramelli refers again to the existence of Ahreman before the beginning of the fight as the primordial being who was within "Eternal Darkness," but actually the Bad Spirit was in "unlimited Darkness" (Bundahišn I, 4; see Pākzād and Markaz-i Dā'irat al-Ma'ārif-i Buzurg-i Islāmī (Iran) 2005, 5). Contrariwise, for Ohrmazd it would have been impossible to attract his demonic enemy into creation and the limited time. Pahl. asar (lit. without head), like Av. an-arra-, were used with spatial value, while it is Av. akarana- and Pahl. akanārag which were used with temporal force, for instance in the explicit designation of Zurwān as "eternal." On the contrary, Ramelli's (2017, 378-80) reference to the passage of Moses bar Kepha (813 ca.-903), in which it is stated that the two principles "crashed into one another/assaulted one another. And darkness had the impetus to ascend, in order to mix with those and among those [...]," is very pertinent for a direct comparison. Furthermore, Bar Kepha knows the Iranian doctrine of the historical 'mixture' (although in another form), i.e. of the period of battle between good and evil forces in the world, a very important doctrine in the Zoroastrian tradition (see again Ramelli 2009, 378-90).

20 See, for instance, the Addendum on the Religious Minorities to the Peace Treaty signed at the end of the Lazika War; see Panaino (2010) and Panaino (2014) with additional bibliography.

21 Dilley in Gardner, DeBuhn and Dilley $(2018,101)$; see also the new edition of this text in Gardner, DeBuhn and Dilley (2018, 150-61). See Panaino (2017f).

22 Ramelli is probably right $(2017,356-57,371,377-81)$ when she remarks that Bardaisan of Edessa, who also supported an earlier version of the doctrine of universal restoration, was certainly acquainted with Iranian ideas, although this does not show that this special interpretation was due to Mazdean influence. It is probable the opposite, that Bardaișan was one of the channels through which apokatastasis became progressively known in Iran. The notion in Bardaisan (via Ephrem) that the Cross of Jesus Christ was the crossing bridge toward the salvation lost and precluded by Adam is very interesting, as remarked by Ramelli (Ramelli 2017, 371). Although it is not explicitly documented, it is possible that the idea of a crossing point was connected with an Iranian idea; see Tardieu (1985). 
its appeal. ${ }^{23}$ Furthermore, we must observe that the Mobedān were no longer responsible for secular law and for the control of social order, so that problems connected with political governance were now transferred to the shoulders of the Muslim authorities. In this completely changed framework, ${ }^{24}$ the optimistic perspective of complete mercy for everybody, even for criminals, was a helpful tool for a decaying religion compelled to maintain a certain degree of attraction, at least in the eschatological perspective. ${ }^{25}$ But, as I noted before, this answer was not found in one shot, and in my opinion its determination had a long and intricate background.

We must consider that the theological solution which we can find in late Pahlavi sources, such as the Škand Gumānig Wizār (Doubt-dispelling exposition), insists on a number of ideas that must be ascribed, at least in part, to the influence of the Aristotelian doctrine of the so-called 'golden mean' (in Pahlavi paymān), which was strongly argued in the Nicomachean Ethics (2,6, 1106b-1107a). The Škand Gumānig Wizār IV, 100-101, declares (Menasce 1945, 58):

[...] and at the end, the highest Creator, who donates mercy (abōxšāyidāar) to creatures, does not let any of the good creatures into the hands of the enemy; He saves the sinners together with the right ones, separating them from the sin thanks to the hands of the purifiers and brings them to the eternal path of beatification.

[...] ud abdom xwābar dādār ì dām abōxšāyìdār ēě dām ì wēh andar dast grawīh $\bar{i}$ dušmen nē hilēd ud ān-iz ì wināhgār gumē ān ì ahlawān pad wizārdārīh ì wināh az yōǰdāhrgarān dast bōzēd ō nēk rawišnīh i ǰāwēdānag zāmēnēd.

This doctrine is not isolated; we can, in fact, mention the most important statement formulated in the Anthologies by Zādspram XXXV, 47 (Gignoux and Tafazzoli 1993, 13637), who attributed the definitive act of mercy to the "Spirit of the Earth" (mēnōg $\bar{\imath}$ zamig): He "will forgive" (abaxšāyēd) all creatures, both the "right ones" (ahlawān) and the "sinners" (druwandān), in the name of Ohrmazd. It is pertinent to note that the verb adopted in order to refer to the deliberate act of "having mercy" or of "being compassionate" was abaxšāy-, abaxšayidan (or abaxšĩdan; MacKenzie (1971), p. 2), the basic meaning of which was "to give the (proportional or expected) part." ${ }^{26}$ Zādspram emphasized the fact that divine mercy would

23 The demographic collapse of the Zoroastrian community became progressively dramatic, and despite strong resistance in certain districts, the number of Zoroastrians who converted to Islam increased not only because of persecutions or discriminations but also for economic reasons, particularly concerning the taxation system (see Choksy 1987, 1997; Kestenberg Amighi 1990; Stickel 2007; Daniel 1993; see also Bulliet 1979, 16-32). Kavvadas (2016, 1-2) remarks that the apocalypse of John Hazzaya shows a first-hand experience of the ongoing Islamization.

24 Although I insist on the circulation of ideas between East and West, the treatment of a subject so sensitive as that of the destiny of the soul cannot be separated from a re-consideration of its social impact in a precise historical framework. A similar consideration is present in the first steps of Ramelli (2017, 351-54), which follows some (in my opinion too) general reflections offered by Bruce Lincoln (1985, 2007b, 2007a) and van den Heever (1993, 2005a, 2005b) and Simmons (2015), although the historical background and relevant impact of the phenomena under discussion does not seem very consistent.

25 Another line of investigation concerns not only the plausible impact of Christian apokatastasis on some theological trends attested in classical Islam that directly concern the annihilation of hell, whose relevance was recently studied by Demichelis (2018), but also on the later Zoroastrian vision of the final renovation (see Ramelli 2017, 399). We must also remark that the standard Islamic doctrine assumes that hell is eternal; see El-Saleh (1986, 47-50).

26 See baxtan, baxš- (to distribute), baxt (part, sort, destiny). On this subject, see Panaino (2013b, 137-45). A similar terminology occurs in Manichaean sources; see Durkin-Meisterernst (2004, 3:15): Parthian abaxšāh(to have mercy), Parthian abaxšāhišn (mercy, pity), Middle-Persian abaxšāy- (to have mercy), Middle- 
be given by the divinity of Earth in her maternal quality. Zādspram's brother, Manuščihr, who was most conservative in religious matters, shared the same optimistic theological vision. Actually, in the Dādestān ì Dēnig ([Book of the] Religious judgements) XXXVI, 106, it was he himself who equally stated: "all mortals, without distinction (lit. kadām-j̄ān-iz 'everybody'), will be without envy towards the goodness of all the creatures and will benefit of the same peace" (Jaafari-Dehaghi 1998, 150-51). This agreement between the two brothers seems to imply that the theory of universal mercy was not a radical innovation during their time but that it was fixed before, although it assumed a mature formulation only in the theological treaties of the ninth century CE. In support of this solution I must quote another piece of evidence, the importance of which was recently suggested to me by Samra Azarnouche. ${ }^{27}$ With regard to the above-quoted passage of Yasna 46, 11, the Pahlavi scribe felt it necessary to comment on the Avestan expression yauuōi vīspāi, ${ }^{28}$ fittingly translated hame tā $\bar{o}$ wisp "forever" (Malandra and Ichaporia 2013, 72, 142, 196), the explanatory gloss tā $\bar{o}$ tan $\bar{\imath}$ pasēn "till the (occurrence of the) final body (tan i pasēn)" (Dhabhar 1949, 203; Malandra and Ichaporia 2013, 72). This solution logically implies ${ }^{29}$ that at the time of the reaction of the Pahlavi commentary to the $G \bar{a} \theta \bar{a} s$, which arguably falls into the Sasanian period, at least some priests had assumed a temporal limit for infernal punishment and made it clear in the commentary. ${ }^{30}$

The consideration that no historical sin should be punished with eternal damnation was adopted as a strong argument supporting the representation of the infinite love of Ohrmazd, and, in contrast with the spirit of revenge apparently attributed to the highest divinity in other religious traditions, in particular against Islam. Concerning this preoccupation, we must recall that a well-known New Persian Mazdean text, the 'Olamā-ye Eslām (The Doctors of Islam) (Olhausen and Mohl 1829, 7; Vullers 1831, 61; Blochet 1898; Unvala 1922, 2:8; Dhabhar 1932, 455), ${ }^{31}$ insists on the presence of one of the Amahraspandān, Ardwahišt, in hell. There, he expressly ensures that the devils do not punish sinners beyond the limits established for their own crimes. This idea is not a late development but can already be found in the Bundahišn (Primordial Creation), ch. XXVI, 35 (Pākzād and Markaz-i Dā'irat al-Ma'ārif-i Buzurg-i Islāmī (Iran) 2005, 299). ${ }^{32}$ This point of view, strongly related to the concept of proportionality between sin and punishment, is not unrelated to Mazdean speculations about the idea of time and, in particular, about the dialectics between infinite and limited time. In fact, the most important objection against the permanence of hell concerns the complete end of limited time and the total renovation of Earth. If hell endures after the fall of Ahreman and the triumph of God, we must postulate that in a remote part of the universe, an antagonist dimension should continue to exist in time and space in spite of the final defeat of evil. But this solution would imply a bold theological contradiction. Correctly, the late formulation of Mazdean theology

Persian abaxšāyišn (mercy), Parthian abaxšāyišngar (pitiful, merciful); New Persian baxšĩdan, baxšūdan (forgive, give mercy); see also Reck (2004, 95, 182).

$27 \quad$ Email dated May 10, 2018.

28 See Kellens and Pirart (1990, 2:26, 293 about the free dative of time).

29 The theoretical possibility that a Pahlavi gloss might have been added later cannot be excluded $a$ priori, but seems to be less probable.

30 To the dossier of sources concerning the refusal of eternal punishment I must also add another passage from the third book of the Dēnkard (ch. 107; see Menasce 1973, 79-80); see also the doctrine formulated in the same book in chapter 272, which is discussed in the following pages.

31 This passage has been discussed recently in Panaino (2017c, 38).

32 I must thank Samra Azarnouche for calling my attention on this fitting passage. See also Bartholomae (1904, 1265n1). 
considers such a perspective as completely impossible. ${ }^{33}$ The victory of God must be complete, it argues, and in fact a river of molten metal will radically consume all of hell. Ahreman, according to a deep speculation of probably Aristotelian origin (see already Zaehner 1956, 83-84, 143-44; Panaino 2005), will not be properly destroyed, because, being a primordial substance, he cannot actually be reduced to nil; the argument goes that Ahreman will be reduced to a condition of in-potentia, from which the Prince of Darkness will no longer be able to resurge and re-act (Panaino 2005). In this respect, late Zoroastrian theology brings some ideas, probably already present in the philosophical debates of earlier periods and presumably already current in Sasanian times, to its most coherent and radical intellectual limits. The myth of free choice transferred to and assumed by the primordial Frawahrān before their earthly incarnation (Bundahišn III, 26-27), ${ }^{34}$ for instance, insists on the existence of a sort of gentlemen's agreement between humanity (before incarnation) and God. There is a sort of impending 'alliance' with a clear promise (and an implicit contract) between the two parts. Practically, it presupposes that the mind of human beings can easily be seduced and that these poor persons will probably sin, but this premise also assumes that it is thanks to their role in history and their direct contribution to the development of humanity that the enemy will be defeated. Thus, it also involves the promise that all of humanity, in spite of its sins and mistakes, will be forgiven after some inevitable punishments and granted access to paradise. In other words, it seems that in the Zoroastrian system, the possibility of sin was considered not only as a probable but as a quasi-inevitable occurrence. In this respect, it was the primordial decision taken by the Frawahrān to live in the gettig as an act of salvation, in se et per se. The coherent elaboration developed in the Bundahišn and in other Pahlavi sources, although under the influence of the contemporary philosophical debate that took place in ninth-century Baghdād, it surely began earlier. ${ }^{35}$ For instance, in the Dēnkard III, 251 (Menasce 1945, 25859), it is clearly stated that without the gètig there is no access to the Wahišt, 'paradise'; and the Mazdean writer insists on the fact that the doctors of other religions who despise the gettig also despise the Wahišt because they assume that most human beings will be druwand and thus go to hell forever. But if this were to pass as they suppose, it would mean that even God's actions are negative. This speculation is very deep because it connects the indispensable experience of the life in the gettig as a sort of passage which God has imagined in order to purify the world itself and, with it, also his weak individual human creatures.

This doctrine probably has a distant precedent in the refusal performed by Yima in accepting the Daēnā offered by Ahura Mazdā, according to a very difficult myth preserved in the second chapter of the Widēwdād. As I have explained in other works (Panaino 2013a, 2015b), this behaviour was erroneously interpreted as a pagan refusal of 'Zoroastrian theology' ( $=$ daēnā-), not as that of the immediate meeting with Yima's own spiritual double in feminine form (equally named daēnā-). In fact, in the second case, the union with the Daēnā, i.e. Yima's

33 Dr. Marco Demichelis (Universidad de Navarra) kindly informed me that Ibn Taymiyya (1263-1328) developed a similar idea in the framework of Islamic speculations on the annihilation of hell.

34 The numeration of the chapters adopted here follows the numeration proposed by Pakzad (2005, 52-53); see Anklesaria (1956, 44-45). See Zaehner (1955, 324, 336), and the discussion in Ramelli $(2017,384)$.

35 I must remark that Ramelli (2017, 381-90), following some remarks of M. Boyce (1975, 8:242-44), who fittingly observed the presence of different variants in the description of the final times in the Bundahišn, concludes too simply that this Pahlavi book was not clear on the final destiny of the souls of the sinners. In my opinion, despite some repetitions and inconsistencies, such as the imposition of a second judgment to the wicked ones, the Bundahišn does not contain any statement concerning the total annihilation of the sinners. On the contrary, the river of molten metals works as a purifying collective ordeal that grants them all access to paradise. Other, later Pahlavi sources confirm this conclusion, and there is no need to make more complex what is clear (see Gignoux 1968, 241-42). 
spiritual feminine twin, would have been a tremendous prize. Thus, the miscomprehension of the initiatory dynamics of a primordial myth in which Yima was expected to refuse the Daēnā in order to meet with her only later, after the full accomplishment of his duty, was mistakenly considered as a sin by later Zoroastrian interpreters, and by modern scholars as well. But this version is unable to explain why Ahura Mazdā, the supreme Zoroastrian God, did not severely punish Yima. Why would Ahura Mazdā have transferred to him the supreme power to multiply Earth and create the Vara, a decision that looks like an act of recognition and not like a punishment for a 'pagan' primitive man who had rejected God's true religion? ${ }^{36}$ More probably, Yima answered exactly as God expected of him, i.e. with a (temporary) refusal of the Daēnā, to be interpreted in this framework as the expected twin (and spiritual double) of Yima, and not as the theological corpus or the incarnation of the 'religion.' This kind of intellectual abstraction corresponds to a very improbable association when we try to project it to the context of an archaic myth, but is the fruit of a later misinterpretation of the initiatory dimension of this passage. Thus, we may presume that Yima, refusing in that moment the Daēnā (taken as his female double), was in reality accepting the role of civilising hero of humanity, and for this reason he was given the privilege to multiply the dimension of Earth and to protect humanity. With his refusal of an immediate beatification ( = the union with his most beautiful feminine double), he accepted his duty for the sake of humanity and of Ahura Mazdā's project against the demons.

Coming back to our main subject, we must underline that a theological discussion concerning the need of a reasonable proportion between sin and punishment was held in the frame of an epistolographic exchange between two monophysites of Syria in the sixth century CE. We know that Jacob of Sarug (or Mar Ya'qûb), in fact, wrote a letter about the final judgment (with reference to Matthew 25) and, in particular, about the eternal punishments occurring in hell to Stephen Bar Sudaili, a monk. In his previous letter, the young monk had wondered about the legitimacy of divine justice according to which a human sin, committed in the course of limited time, could find eternal punishment in hell. In this case, as underlined by Guillaumont (1979), ${ }^{37}$ who commented on this passage, Jacques gives an answer based on an argumentum per absurdum, declaring (ibidem):

for if it be not just that He (i.e. God) should cast into everlasting fire him who has sinned during a short time, as is written; then also it is not just that He should cause him who has been righteous during a short time to inherit the everlasting kingdom. And if it seems to thee that the sinner should be judged according to the number of years during which he has sinned, it would then follow that the righteous should enjoy happiness also according to the number of years during which he practised righteousness. So that he who sinned during ten years would remain in the fire for only ten, and he who practised righteousness for ten years would also remain in the kingdom for only ten years and would then leave it.

Then, Jacob concludes: "The sinner who does not repent, if he had lived forever, would have sinned forever, and according to the inclination of his mind to continue in sin, he justly falls into everlasting hell."

In other words, the explanation, which, of course, implicitly tries to counter the Origenian

36 See, for more detailed arguments, Panaino (2013a, 91-131, 2015b).

37 The same letter was already published by Frothingham (1886, 10-26, in particular 18-21). 
doctrine of the apokatastasis and of the universal liberation of sinners from hell, insists on the fact that God punishes the intention of the sinners.

In the economy of our discourse, it is important to recall that East Syriac ideas on apokatastasis could give additional weight to the present arguments. ${ }^{38}$ Although it may seem peculiar, we must emphasize the fact that even the rector of the Theological School of Nisibis (Widengren 1984, 18-19), ${ }^{39}$ Henānā, who was elected in the year 572, had a positive attitude toward Origen and Origenism, and certainly played a very significant role in Sasanian Iran. But his case is not unique: Joseph Hazzaya (or Yūsuf Ḥazzāyā) (Scher 1909, 1910; Beulay 1974; Kavvadas 2013, 2015), ${ }^{40}$ an eighth-century author of Zoroastrian background (born around 710-13), who was forcedly converted to Islam and then became Christian, apparently argued for a complete end of infernal punishment. ${ }^{41}$ The previously mentioned Christian monk, Stephen bar Sudaili, probably identical to the author of the controversial Book of Hierotheos on the Hidden Mysteries of the House of God, ${ }^{42}$ equally argued for apokatastasis, ${ }^{43}$ showing seminal reflections of a number of contacts between Syria (Edessa) and Palestine, ${ }^{44}$ which developed Origenian trends along the direction given by Evagrius. (Guillaumont 1958, 1962; Reinink 1999b)

These and other sources patently show that the debate about the final destiny of sinners and the reflexes of the Origenian doctrine concerning absolute divine mercy that will liberate them all after the final judgment was at least known in Syria and Eastern Christianity. ${ }^{45}$ Thus, we can assume as certain the presence of such a theological and legal amphiboly with logical terms that would perfectly fit even into the Mazdean theology of a few centuries later. The rationale to be attributed to an intrinsic proportional rate between fault and punishment was not an abstract thought but part of the theological-philosophical agenda of late Antiquity among the Christian communities of the East. The presence of similar assumptions in later Zoroastrianism compels us to evaluate the weight and the extension of this intellectual exchange. We know that in the Zoroastrian framework, Aristotelism ${ }^{46}$ and the doctrine of the

$38 \quad$ I must thank again an anonymous reviewer for his or her pertinent and supportive suggestions.

39 See also Reinink (1999a, 182-87). About Ḥenānā and the School of Nisibis, see Vööbus (1965). See also Molenberg (2017, 152-55).

40 Kavvadas (2016) has edited the Syriac book On Providence, which confirms the Origenist doctrine of the apokatastasis in Hazzaya. Kavvadas (2016, 14-15) well describes the origins of Hazzaya, remarking the fact that he was the son of a Mazdean priest of Nemrud, seized by Arab soldiers. The personal experience of Hazzaya must be considered in the framework of a special social background, in which the doctrine of universal salvation represented a strong answer to widespread distress and sufferance. If this was a sentiment current among Christians, we can doubt that the Zoroastrians were more optimist.

41 See the most recent edition of the treatise On Providence by Joseph Hazzaya, edited and translated by Kavvadas (2016). In his arguments, Hazzaya followed some aspects of the doctrines developed by Theodore of Mopsuestia, also shown by Kavvadas (2016, 9-12). Joseph Hazzaya was considered heretical by Timoteus (see Berti (2009)).

42 See the edition by Marsh (1927); see also the earlier work by Frothingham (1886). On this text, see Ramelli (2013b, 772-73). Prof. Emiliano Bronislaw Fiori (University of Venice, Ca' Foscari) informs me that he is working on an Italian commented translation of the Book of the Hierotheos.

43 See Marsh (1927) and Frothingham (1886, 51-55, 63-66, 73). Bundy (1986) has identified the presence of Manichaean motives in this source, following some remarks already advanced by Guillaumont (1962).

44 I must thank my colleague Prof. Lorenzo Perrone (University of Salento) for his precious comments and advice.

45 In particular, it was Marsh (1927) who followed the impact of these doctrines in authors like Theodosius and Bar Hebraeus (see also Pinggéra 2002); the reappraisal of Origenism in the ninth and twelfth centuries has been the subject of a careful investigation by Reinink (1999b, 2010). Chialà $(2002,2014)$ has studied the subject of the apokatastasis in the framework of the Persian Church with particular attention to Isaac of Niniveh (see also Brock 1995). I must thank Prof. E. B. Fiori for his kind advice on this particular problem.

46 On the knowledge and diffusion of Aristotelian doctrines in Iran, see already Casartelli (1884, 1889); Zaehner (1955); Bailey (1971); Shaki (1999). 
good medium had a certain influence, so that these speculations may reflect a common sensibility. This evidence emphasizes some peculiar comparanda which we can find in the Mazdean apocalyptical events, such as the river of molten metal, which all the dead will enter and which will purify all sinners for three days and nights. Despite the fact that in Iran, it is not 'fire' that purifies sinners, as in the river of fire ${ }^{47}$ described by Origen ${ }^{48}$ (e.g., in the Homilia in Lucam $24),{ }^{49}$ the two traditions are strongly resonant, if not properly similar. The problem again rotates around the idea of divine goodness and its limited or unlimited mercy, and about the role of hell. The Zoroastrian solution, in its final version, underlines the incompatibility of the last victory of Ohrmazd and of the final dissolution of the limited space-temporal dimension with the co-existence of another, limited, separated (mini)-universe into which sinners and demons would be thrown forever. Its endurance would be, as noted before, a contradictio in adjecto, practically as a defeat or an objective limitation for Ohrmazd's universal power. Hell, in fact, will stand as a limit against his unlimited kingdom of light. ${ }^{50}$ The Iranian apokatastasis corresponds to a regeneration of the world in which even divine creation gains perfection. In fact, from the primordial phase, before the determination of limited time, Ohrmazd and Ahreman had to coexist in the universe; now, after the period of mixture, the gumēzišn, Ahreman will

47 The antecedents of this image can be seen in the Apocalypse of Peter (Bremmer 2009, who thinks that it derives from Plato's Phaedo 114a), but also in the second book of the Sibylline Oracles, 190ff., where we

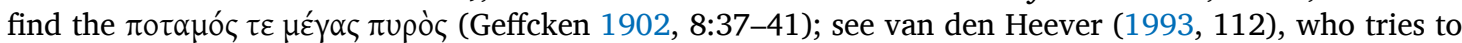
derive some Christian ideas from earlier Zoroastrianism. Unfortunately, the image of a cosmic burning is not at all Zoroastrian, but is attested in Manichaean sources. About the Apocalypse of Peter and the river of fire, see Ramelli (Ramelli 2017, 386). Very important is the study by Himmelfarb (1983, 110-14).

48 See Edsman (1940, 1949); Guillaumont (1946); Anrich (1902); Müller (1958); Cornélis (1959); Ramelli (2009, 2013b, 98, 122, 273, 561, 2013a); Lettieri (2011, 284-86, 2017a).

49 Migne (1862, 1864-5): Sic stabit in igneo flumine Dominus Jesus iuxta flammeam romphaeam, ut quaecumque post exitum vitae eius, qui ad paradisum transire desiderat, et purgatione indiget, hoc eum amne baptizet et ad cupita trasmittat: cum vero, qui non habet signum priorum baptismatum, lavacro igneo non baptizet, Oportet enim prius aliquem baptizari aqua et spiritu, ut cum ad igneum fluvium venerit, ostendat se at aquae et spirtus lavacra servassae, et tunc mereatur etiam ignis accipere baptismum in Christo Jesu: cui est gloria et imperium in saecula saeculorum. Amen. "In the same way, the Lord Jesus Christ will stand in the river of fire near the 'flaming sword'. If anyone desires to pass over the paradise after departing this life, and needs cleansing, (Christ) will baptize him in this river and will send him across to the place he longs for. But whoever does not have the sign of earlier baptisms, him Christ will not baptize in the fiery bath. For it is fitting that one should be baptized first in 'water and the Spirit.' Then, when he comes to the fiery river, he can show that he preserved the bathing in water and the Spirit. Then he will deserve to receive in addition the baptism in Christ Jesus, to whom is glory and power for ages and ages. Amen." For the translation I have followed Lienhardt (1996, 103-4). See also Frayer-Griggs (2016, 5-6, 13, 73-75, 142).

50 Ramelli $(2017,370,391)$ in her evaluation of the Pahlavi sources, states that chapter XL, 31 of the Dādestān i Mènōg $\bar{x}$ xrad XXX, 31 (or Judgments of the Spirit of Wisdom) confirms the earlier Avestan doctrine of the eternal punishment of sinners. However, the text is more ambiguous, and the old interpretation of the passage given by West $(1885,3: 81 \mathrm{n} 4)$ already takes into consideration some well-argued alternatives. The passage (so translated by West "And the bridge and destruction and punishment of the wicked in hell are for ever and everlasting") actually reads as follows: puhl ud drōš ud pādifrāh ì druwandān pad dušox tā hame $\bar{e}$ u hame-rawišnih [...] (the bridge and the punishment and the retribution of the wicked ones are in the hell for-ever-and-ever): This statement can be taken as a witness of eternal punishment, but also, as West suggested, to the entire time of the fight between Ohrmazd and Ahreman, which will last until the resurrection. In the preceding paragraph, tā hamē ud hamē-rawišnih (for-ever-and-ever) is clearly used for an (apparently) eternal paradisiacal state, so that, in the second case, it should refer to the eternity of the punishment, but again, West claims that this conclusion is in contradiction with the rest of the Pahlavi statements concerning the destiny of all souls. In my opinion, the text offers a symmetric presentation of the afterlife, so that the two states are presented in their dimension with respect to the present time, which is not that of the final renovation. When the wicked are judged and purified in the river of molten metal, their punishment would be meaningless if it did not contain an additional emphasis on their previous impiety, but not as a future eternal perspective. With the destruction of hell, their place will finally be with the others, as that of Ahreman, who, having been reduced to pieces, will continue to exist not as a kind of a dark infernal active demon but as a mass of blended atoms, no longer in any condition to produce damage. 
be defeated and scattered into pieces while his antagonist creation should be destroyed and the universe finally purified from its contamination. Human beings, thanks to the experience of life in the gettig and after a period in the temporal afterlife in paradise, in purgatory or in a temporary hell, will have access (through the resurrection and the purification in the river of molten metal) to a new dimension of transfiguration, a subject to which Shaked (1970) attracted scholarly attention some years ago and which corresponds to a new ontological state of human beings in which they assume a semi-divine condition. ${ }^{51}$ The postulate of the tan i pasēn, or corpus resurrectionis, appears fundamental in the economy of this reflection because this 'future body' is not just the old one reconstructed but corresponds to a sublime transfiguration of its earlier condition. In this respect, I would like to again call attention to speculation independently developed by Origen (Principia II, 10.2): with reference to Paul, Cor. XV, 35-50, he states that the body, which will resurrect, will be a "spiritual" one, starkly different in its transcendental habitus from its present status (Fernández 2017). The difficulty of imagining a resurrected body, perfect, eternal, finds common inspiration in the idea that it cannot be just as it was before, an idea that, for instance, was not at all unknown among early Christian writers, who simply stated that God in his absolute power can do anything (as Celsus, for instance, assumed). I must again call the reader's attention to the fact that in the third book of the Dēnkard (ch. 272), Ohrmazd will raise the soul from hell, washing and dressing it with a new substance before admitting it to eternal immortality (ǰāwēdān anōšag) and full happiness (purr-urwāhm; Menasce 1973, 273). The similarity of these images, and the Mazdean emphasis on the tan i pasen (the future body), certainly deserve further comparative investigations. ${ }^{52}$

51 We must recall that in the later Mazdean tradition, the individual souls (more precisely the Frawahrān) are expressly asked by Ohrmazd (Bundahišn III, 27; Pākzād and Markaz-i Dā'irat al-Ma'ārif-i Buzurg-i Islāmī (Iran) 2005, 53) to accept the incarnation (Zaehner 1955, 324, 336); this choice necessarily compels them to suffer in real life, and inevitably introduces the risks of demonic seduction. But the promise is God's final mercy. In this respect, human beings share the same idea of the Deus patiens, because the main historical sufferance is attributed to them. For the Gnostic and Origenian aspects of the idea of the Deus patiens, see Lettieri (1996, 2005, 186-89).

52 I must thank one of the anonymous reviewers of this article when he remarked that some pertinent differences should also be emphasized. For instance, the radical apokatastatic doctrine in Christianity implies the salvation of the Devil and demons (Lettieri 2017b, also with reference to Eriugena), as in the anathemas against Origen (and a return to an undifferentiated Monad, e.g. in the Book of Hierotheos). About this source, see below in the text. On the contrary, although Ahreman is not properly destroyed, he is rendered unable to act again, but certainly not redeemed (see Ramelli 2017, 374-76). In other words, the Prince of Darkness cannot actually be destroyed in a physical or material sense, but he can be put in a state of total impotence and fragmentation. On the other hand, we must remark that Ahreman invoked Ohrmazd's help when the demon Âz was ready to eat and kill him at the end of the fight with the divine forces. In that case, Ohrmazd saved him but could not let him go free, and thus paralyzed his being. Furthermore, the Origenist Christian doctrine of apokatastasis implies that evil is not a subsistent essence per se, therefore it cannot last forever; on the contrary, Ahreman is a primordial principle. I have dealt with the ontology of Ahreman in another article (Panaino 2005), and I must remark that the Mazdean theology in this case follows some Aristotelian patterns, which attributed to Ahreman the dignity of a primordial substance. In this regard, I wish to emphasize that it is not my intention to demonstrate that the two religious trends were similar, but only that they shared some important points, and that these correspondences require a discussion. In addition, although the controversy against Origen presents some obscure points, the theory that the accusations against him did not really represent his original doctrines but only those of his followers, or again that they consist of distortions or exaggeration of his thought, is far-fetched and sometimes based on confessional arguments, as those suggested by Crousel (1985) and few of his followers. In this perspective, Evagrius (Guillaumont 1958, 1962; Chialà 2002, 101-9), who was severely condemned, as was Gregorius of Nissa, another faithful disciple of Origen, followed his master (Hombergen 2001). I must thank Prof. Gaetano Lettieri for his remarks on this particular problem. Again with respect to the end of evil, we must observe that the Manichaean solution, in turn, involved a complete damnation of evil, but according to a completely different theology, which did not reflect the Zoroastrian 


\section{Circulation of Ideas and Multilateral Exchanges}

The observation of these striking similarities invites us to reflect on the ways of transmission and communication in a rough scheme based on the pattern of direct and unilateral influence. ${ }^{53}$ The Sasano-Byzantine border was a territory of ancient civilizations where extraordinary cultures had continuously contributed to the progress of the material and immaterial cultural development of humanity. Jewish-Christian chiliasm remains inexplicable without the influence of the Irano-Mesopotamian tradition, but new developments that these millenarian doctrines assumed in the Christian framework inspired new reflections in the Eastern world, and their resonance was also visible in Iran. The insistence of some scholars that Iranian eschatology is strongly indebted to the Judeo-Christian world, as assumed by Ph. Gignoux and C. G. Cereti, is correct, and my contribution probably enforces this interpretation, but with the prudent consideration that other ideas, coming from the East at earlier points in time, entered and deeply inspired the Judeo-Christian world. This must be considered in light

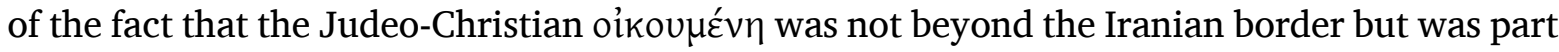
of its political space, and that continuous interrelations were possible among these religious communities. One of the main risks we must face concerns the fragmentation of a cultural mosaic, which sometimes is seen as made just of single pieces, but without the perspective of a more general and integrated view. A confessional trend which underlines the distinctive character of each religion frequently discharges the compelling evidence of objective intercultural phenomena which disentangle our ordered vision of the postulated difference. For instance, I am wondering whether the sentences against Origen in 543/44 and 553 were just an inner Byzantine problem, faced and resolved by Justinian, or if there were other reasons for them as well and, eventually, external implications and reflections. Although one might observe $^{54}$ that this kind of Origenism seems mostly a Palestinian phenomenon, ${ }^{55}$ reasonably

doctrinal vision, although some points appear to be similar. In this regard, the idea of the bolos, in which all sinners and demons will be thrown, is extraneous to the Zoroastrian point of view and seems to belong to a more properly Gnostic perspective. In the framework of the Zoroastrian speculation, it is clear that no eternal Hell is possible because its existence and permanence would imply the presence of a limit in the universe. In any case, its endurance, although as a place of diminution and punishment, represents a space in which Ahreman will reign and in which Ohrmazd will be extraneous, while divine victory must be universal in time and space.

53 Although I cannot enter into all the problems discussed in other works, there is no reason to search for an overwhelming Iranian influence on the Christian doctrine of universal salvation, which, in fact, was not attested in ancient Iranian sources. See also the discussion in Ramelli (2017, 361-62). The famous passage by Plutarch, De Iside et Osiride 46-47, based on a fragment by Theopompus (IV. century BC) on Mazdeism, simply states that Ahreman will be annihilated at the end of the fight with Ohrmazd but does not develop other eschatological concepts in extenso. In any case, in it there is nothing that could be referred to as supportive of the apokatastasis, but also of a cyclical idea of time periods, which is completely extraneous to all attested Mazdean doctrines, despite what Ramelli $(2017,374)$ remarked. It is true that the text states that Ohrmazd's soul will sleep for a certain time, but there is no reference to a resurrection of Ahreman and to a new fight.

54 Again, I thank one of the anonymous reviewers for his or her comments.

55 But this phenomenon was very significant; for instance, among the most enthusiastic Origenists of Palestine, we find Domitianus and Theodorus Askida, who were so able to secure the support of the court that they were elected bishops in Ancyra and in Caesarea of Cappadocia. The Palestinian turbulence was so heavy that Justinian decided to force the rebels back to order with his Caesaropapist politics and to persecute the extreme Pagan allegorical images usually adopted within the Origenist milieu. Although 'provincial', these phenomena had their own external spillovers. I must thank Prof. Gaetano Lettieri (University of Rome, "La Sapienza") for his advice on this aspect of the controversy. 
confined to a handful of monasteries ${ }^{56}$ and influential individuals, ${ }^{57}$ so that the degree of impact this anathematization would have had outside Palestine and the capital is questionable, ${ }^{58}$ such a conclusion is debatable if we consider that two different Imperial sanctions against it were deliberated. Justinian himself promoted them, and on the second occasion, the final deliberation was confirmed by an Ecumenical Council. Regarding the 'Palestinian' dimension, this area was certainly influential and, despite its provincial frame, developed a good net of connections. Furthermore, my attention strictly concerns the spirit of this action in the framework of Justinian politics. ${ }^{59}$ Was an eschatological representation of divine tolerance, in itself so deeply (though not exclusively) connected with the Origenian doctrine of the apokatastasis, also considered a political danger, in particular within the balance of the social equilibrium? ${ }^{60}$

In these years, Mazdak, ${ }^{61}$ a Zoroastrian priest, full of egalitarian and semi-socialist political and religious ideas, started a radical process of social reforms which had a significant impact on Sasanian society and even on its kingship. The echo of its radical actions was enormous and reached the West. We do not know if the Mazdakite progression in Iran and its reflection in Byzantium involved similar eschatological perspectives, but when one considers that with the potential collapse of private property and legitimate succession, the movement of Mazdak opened new expectations, we can reasonably presume that some radical hopes

56 The monasteries have played an important role as cultural agencies in the preservation and dissemination of the Christian tradition, so that what happened there was not at all isolated or remote. Very interesting in this context is the volume collected by Fr. Jullien (2011) dedicated to Oriental Monasticism, which strictly deals with the function of these Christian institutions.

57 As, on the contrary, one of the anonymous reviewers to this article remarks. On the other hand, Kallistos Ware (Ware 2005, 198-205, passim) presents the scenario in a much more complex way; the circulation of the Origenist ideas is highly interesting.

58 We should not forget that Guillaumont (1962) has shown that, despite its damnation, Origenism did not disappear but, on the contrary, gained some supporters in the Eastern Syriac Church. In the same study, Guillaumont was able to show that in the year 553, the doctrines of Evagrius were the object of the main accusations. The echo of the events happening in the Eastern Roman capital had immediate reflections in Sasanian Iran and in the Eastern Syriac area, because Constantinople was not only a place in which the official Sasanian ambassador had his residence and status but also a city in which Persian spies were active.

59 As is also visible in the context of the international treaty regarding the Lazika Pace, Justinian maintained a very high level of attention to Iranian affairs, and it is clear that the position of Christianity there was significant for him (Panaino 2009b, 2010, 2014, 2015a). See e.g. Guillaumont (1969) and also Frendo (1997).

60 Although I cannot find any direct relation with the Mazdakite movement, it is interesting to note that one year before the second anathematization of Origen, a tremendous revolt (usually referred to as 'Nika') took place in Byzantium, which produced dramatic events. The presence of Manichaean elements in the "Green Faction" of Byzantium shows the complexity of some religious and political phenomena, in particular if we consider that the Manichaean element had its main social basis in the merchants' ambiance; but more interesting is the suggestion made by Jarry (1960, 366-68, 1968; and later emphasized by Carile 1994, 50) regarding the Western resonances and adaptations of Manichaean and Mazdakite doctrines. In particular, Jarry underlined the importance of a suggestion given to Justinian by the Byzantine noble Erythrius, whose wife was credited to be Manichaean (according to Malalas 1831, 423) and who was Praefectus Pretorii under Zeno (see Müller 1851, Quartum:116). This nobleman (see Martindale 1980, 2:402), in fact, would have proposed the adoption of the Mazdakite doctrine in order to conquest the whole of Asia (Carile 1994, 50). Furthermore, Jarry insists on the connections between the Byzantine revolt of the year 552 and Manichaean and Mazdakite ideas. Recently, Ramelli (2017, 253-54), too, tried to frame the apocalyptical Iranian doctrines in a sort of political dimension, but her approach does not take into consideration the Iranian dialectics between nationalism and universalism, which were well studied by Gnoli (1984). Certainly, we must recognize that the earlier Iranian vision of world history did not emphasize a universalistic perspective, and that this soteriological aspiration was endorsed by the Manichaean trend (as remarked by Simmons 2015, 190), but that in the direct confrontation against the Eastern Roman Empire, the role of the king assumed a cosmocratic meaning, and that the Iranian political project of expansion had cosmic pretentions.

61 About Mazdak and the Mazdakite movement, see Christensen (1925); Klíma (1957, 1977); Shaki (1978); Sundermann (1977); Yarshater (1983); Crone (1991, 1994, 2012). 
also involved eschatological expectations. For this reason, it is worth considering as a working hypothesis that this political phase might have favoured the diffusion of the idea that even hell would be destroyed. Paradise for everybody would be another sort of 'spiritual communism,' based on the idea that divine insight is full of mercy and generosity. We know that Origen was not appreciated among Dyophysites, but intellectual alliances were possible despite general divergences. Origenism and similar optimistic ideas might have found a path of diffusion in different ways, even via Monophysites, and the common intellectual interest in Aristotelian as well as Neo-Platonic backgrounds created a sort or 'no man's land' where numerous exchanges were possible. For instance, if we consider how it was possible that some court astronomers/astrologers in Sasanian Iran were Christian, we are compelled to observe that, despite a general refusal of astrological divination, many Christians endured practicing a moderate form of astrology, in which the principle of astral pre-determination on free choice was strongly limited (Panaino 2017a). In this respect, the role played by the Magi at Bethlehem represented a double-faced instrument of propaganda. It actually showed that an Iranian traditional practice had inspired some wise men to find the true Saviour, frequently identified as one of the three expected posthumous sons of Zoroaster, but also legitimated a sort of pious practice which could not simply be demonized. But the problem is much more intricate, because astrology was strictly linked with power and its symbolism. In fact, in Iran as in Byzantium, both monarchies used to play with the image of the royal kosmokrátor, placed at the centre of a cosmic hall, where all the stars and the luminaries rotate around the persona sacra of the king as a living Sun. This game was performed on both sides (Panaino 2004a), which imitated each other in many ways, and no religion dared to contrast this esoteric trend in an open way. The Byzantine emperor put himself among the twelve apostles, just like Jesus in a process of 'Cristomimesis,' while the King of Kings appeared to the Byzantine conquerors of Ganzaca as a divinity enthroned in heaven, with angels bringing him sceptres and encircled by the luminaries and the stars. An impressive machine, like a sort of clock, moved around the throne. These and other descriptions of the celestial dimension of the universal king have been reported by Theophanes (ninth century CE) through Georgios Cedrenos (I, 721, 18; eleventh/twelfth century CE; see Panaino 2004a, 564-72), or by the Patriarch Nikephoros (XII, 43-47; eighth to ninth century CE) (see Nicephorus 1990, 56, 57 and @LOrange_Studies_1953, p. 20), but the power of this ideological symbolism was already evident in a short note by the glossographer Hesychius (fifth century CE), sub voce oujpavoù

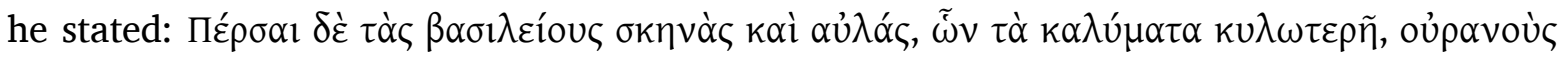

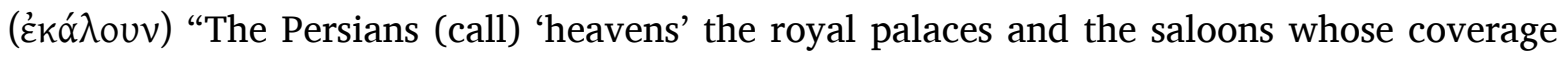
had been made 'round'" (L'Orange 1953, 22).

Furthermore, I would like to call the reader's attention on the fact that the few references in Christian literature of the Church of the East which attest to the presence of Christian astrologers, members of the religious hierarchy, at the Sasanian court, in particular in the Chronicle of Seert, find a distant confirmation in the similar tradition explicitly documented by Chinese sources of the Tang period, in which the arrival of Christian astronomers/astrologers in very high positions in the Central Bureau of Astronomy is emphasized without any possibility of doubt. The most important astrologer, Li Su, was certainly a Christian and a very good specialist in these esoteric disciplines coming from the West, i.e. from the Iranian world, presumably from Persia or Sogdiana. ${ }^{62}$

The significance of this evidence must be emphasized; in fact, the role not only of astrol- 
ogy, but of a kind of astrology developed in the Persian framework gives us a measure of the cultural legacy that emerged in Sasanian Iran and the richness of its ramifications and irradiation. For instance, it is probable that the astrological doctrines contained in the Middle Persian re-elaboration of the Carmen Astrologicum by Dorotheus of Sidon ${ }^{63}$ (first century $\mathrm{CE}$ ) were transferred to China by Christian astrologers who actually became competitors of Buddhist scholars in this field. This exceeds all standard expectation, although, for an openminded historian, reality is much more intriguing than fiction. Previously, we have mentioned the presence of Christian forms of adaptation of astrology, but the subject is more complex because it must be connected, at a higher intellectual level, with the philosophical debate concerning the eternity of the world and in particular of the heavens, and, more pertinently, with the the possibility of the spiritual animation of the astral bodies. This debate was very relevant in Byzantium and among Christians, in the East and West, so that it impacted Monophysites and Dyophysites. Joel Th. Walker (2006, 190-97; see Panaino 2017a) has also found pertinent resonances of these discussions in the framework of the interrogatory of the Sasanian General Mar Qardagh, held during the process concluded with his martyrdom. The philosophical literature of late Antiquity demonstrates that a deep discussion concerning these subjects was known even in Western Iran before the Arab invasion, and that it would be historically reductive to limit the importance of these philosophical controversies only to the ninth century CE. If Theodor of Mopsuestia (fourth to fifth century CE) and Cosmas Indiclopleustes (early sixth century CE) strongly maintained the earlier Aristotelian representation of the heavens and of the astral bodies, assuming that they were given a soul, and stated that angels directed the motion of the sun, the moon and the stars, we can equally trace the violent reaction of a Christian scholar like John Philoponus (sixth century CE), who progressively rejected the idea of the eternity of the heavens and the hypothesis that all astral beings were animated and directed by angelic powers. ${ }^{64}$ It would be interesting to imagine the position of Mazdean scholars, who probably maintained a generic Aristotelian point of view but stated that both the stars and the luminaries were divine beings under the power of Ohrmazd, while the planets, which were demons, although animated, would be destroyed by God at the end of limited time. In this way, the Mazdean wise men adopted only a partially Aristotelian position, without subscribing to the assumption that this world is eternal in its present status; they presumably stated that it would be radically changed with the dissolution of the limited space/time dimension created by Ohrmazd in order to entrap Ahreman, and that a new world was to be be expected. In this respect, the theological matter was likely intellectually intriguing because we can postulate that various kinds of philosophic (dis)entanglements and (counter)-alliances were possible. In this framework, the intolerance of Justinian policy in philosophical matters and the expulsion of the Greek philosophers from the Academy of Athens in 529 produced an additional earthquake, because despite the a priori hostile description of the events given by Agathias (sixth century CE), we can assume that a reasonable interest toward the Iranian world was present in the western scholarly ambiance of that time, and that at least Xusraw I was sufficiently interested in the ideas of these expelled philosophers to host them and eventually to offer them protection on their homeward journey, as we know from ancient sources. Nolens volens, these societies were in close contact, in particular at their highest intellectual levels, so that it is difficult to work out whether they were 'closed boxes' without continuous

63 On this fundamental manual of astrology, see Pingree (1989, 229); for the edition of the original Greek text, see again Pingree (1976).

64 Panaino (2017a) discusses the main terms of this debate and offers a pertinent and extensive bibliography. 
relations. The difference of language was a limited problem, not only because the Syrians and the Armenians played a continuous game of intermediation but also because the political situation necessitated observing the enemy. Collaboration was also required on some occasions, as in the case of the redaction of the treaty signed by the delegations of Xusraw I and Justinian at the Lazika Peace (532 AD). The terms of this treaty were fixed with a bilingual (Greek and Persian; Panaino 2017e) official document, in 11 points, plus a long addendum on religious minorities. Menander the Guardsman (mid-sixth century CE) preserved a synthesis of the original text, but the (Middle) Persian version is probably referred to by Tabari with an interestingly (if not opposing, then surely differently) oriented representation of the facts. This difference clearly shows that these treaties were made public in the two countries in a way which highlighted only the advantageous results, while the necessary concessions offered to the other part were not made public explicitly (Panaino 2009b, 2014). Furthermore, the complexity of the matter and the way in which the bilingual text in Greek and Middle Persian was redacted demonstrates that the level of cooperation was very high (as it is visible in the calendar adopted for the synchronism of the annexed agreements, which followed the "Egyptian style" in order to avoid any preference and any mistake; Panaino 2010), and that the Romans probably had to write the Pahlavi version, while the Persian delegation produced the Greek text (Panaino 2017e). In any case, both sides apparently invoked a God who seems to be the same for both; a very remarkable fact (Panaino 2015a).

My focus on these apparently secondary details seeks to emphasize the multicultural dimension of the theological and philosophical speculations that concurred with the continuous elaboration of Mazdean eschatological doctrines. If I can dedicate the final part of my contribution to some conclusive remarks, I would like to synthetize some aspects of the Iranian process of theological formation, insisting on the fact that, after an original phase of formation and of inevitable dialogue with the surrounding Mesopotamian world, a long period of intercultural exchange with the Greek and Judeo-Christian civilizations transformed the Iranian intellectual world, although this phase was followed by a further re-adaptation of some doctrines that definitively took place in the Islamic period. At that time, again, some protagonists of the debate were still the same: Greek philosophy in Christian, Jewish and Islamic declinations, but the political and military defeat of the Sasanian Empire paradoxically gave more freedom to the inner theological elaboration of the Zoroastrians, no more limited by any raison d'état. The Iranian contribution to the development of human intellectual history maintained its originality because, despite the importance of Aristotelian thought and, to certain extent, also of Neo-Platonic doctrines, late Antique Iran preserved and transformed some fundamental categories originally developed in its secular tradition. This was the case with the distinction between eternal and limited time, between mēnōg and gètig, with the particular emphasis on the fact that evil forces were mainly mental (mēnōg). In this way, the Iranian intellectual world continued to offer de facto one of the most significant innovations with respect to the representation of the relations between mind and body, in which the body assumed an autonomous and very positive function.

\section{The Zoroastrian Idea of Evil as a Mental Dimension}

Another point which must be underlined concerns, in my opinion, the importance of what I would like to call an anachronism of Zoroastrian 'psychology,' which stems from a series of ontological premises. The 'principle' and the 'prince' of evil, which practically coincide, 
are intrinsically a manifestation of something comparable to a mental disease. The first sinner, Ahreman, substantially embodies a mentally suffering drive (mainiiu-) present in the cosmos; his contra-creation, realized against Ohrmazd's luminous world, is the result of an act of self-sodomy, an action which symbolically shows that Ahreman is incapable of loving anybody other than himself (Panaino 2009a, 2009c), and that he is dowered with a strong sexual drive but that this drive cannot be seminal. ${ }^{65}$ The creatures who follow him start to behave, like the first two twins born by Gayōmart, as psychiatric criminals, killing and eating their own first couple of children, a kind of behaviour well known in the manuals of criminal psychiatry. Thus, Zoroastrianism had the extraordinary originality to imagine evil as a manifestation of mental suffering, describing its presence in creation as a mental seduction disturbing and destroying the regular course of life. At this point another interpretative key can be considered when we try to evaluate the Mazdean tolerance in the afterlife and the myth of the Frawahrān's incarnation. The sin is not only a matter of free choice, a problem about which Iranologists have started a long and intricate critical and controversial debate, but a fruit of mental weakness and of inner imbalance.

In other words, the Zoroastrian final optimistic solution of the definitive mercy of God toward everybody, a solution that also includes the sinners of hell, implicitly assumes that the damned are not completely responsible for their faults. Their responsibility is limited, and consequently it is only for this limited part that they must pay for the sins in a temporary hell, which substantially corresponds to a harder purgatory. Here, I see the final effects of some theological presuppositions already visible in the idea that without the gettig, humans do not have the merits to obtain a 'future body'. This body of transfiguration has been practically sainted thanks to the living experience, which works as a sort of self-sacrifice. The decision of the ancestral Frawahrän to descend into the living world results now in an act of auto-salvation; in fact, it opened the path to the final resurrection and paradise to the whole of humanity. A human existence, only mēnōg, will be imperfect, and not suitable to real incremental progress in the ontological dimension. From this point of view, the resurrection of the dead is the seal of their definitive transfiguration. No being can be resurrected in order to go to hell again. It is a pity that we do not possess minutes of theological debates occurring in late Antiquity and the early Middle Ages, apart from some scattered references in polemical documents, such as the Škand Gumānig Wizār, but I am sure that the subject was dramatically deep, and that it probably knew not only external controversies but also many internal, tantalizing discussions. What we know is that at certain point, in a particular political condition, the doctrine of the apokatastasis was officially accepted also in the Zoroastrian world, in a very optimistic and-we could say-'liberal' version, not as a privilege for a restricted number of elects, but as the gift to be expected by all human beings. This solution was not isolated, but its Origenian comparanda was less fortunate, remaining in the limbo of Christian heresies while its modern revivals have opened a number of accusations and controversies, inevitably due to the eschatological importance of this solution. ${ }^{66}$

65 I must emphasize the importance of these aspects, which are foundational in the Zoroastrian representation of the world and in the theological explanation of its meaning, despite the fact that they typically have been ignored. An example of the strong embarrassment subjects such as these are met with is the myth of Ahreman's act of self-sodomy, which has never been the object of a serious investigation until recent years. This silence is very peculiar if we consider that this myth concerns the origin of the antagonist creation of Ahreman, and inevitably involves a number of symbolic meanings. I cannot repeat here the material collected on these subjects (see Panaino 2009a, 2009c). 


\section{Conclusions}

The subject is certainly intriguing and I am not strictly looking for direct influences; ${ }^{67}$ my focus in this investigation remains on the complexity of intercultural dialogue, which was evidently significant and inspired many related or strikingly resonant solutions. ${ }^{68} \mathrm{Just}$ as another provocation, I must remind readers that already in Bardaișan we find a sort of anticipation of the apokatastasis in his doctrine, stating that our world is a mixture of the four elements plus darkness, ${ }^{69}$ but that this condition will be extinguished and a new mixture, although without darkness, will emerge (Ramelli_Bardaisan_2009; Ramelli 2013a). When we consider that apparently even Bardaișan was operating within the theological premises of an ideal temporal framework of 6,000 years (Panaino 2017g), arranged according to an even number of planetary conjunctions, we could suspect that a cross-cultural echo coming from Iran could be possible, and we come back again to a never-ending circle.

What seems to me certain is that in this complicated mosaic of traditions, Zoroastrian theology had its own dignity and complexity, and that without its study a great chapter of the intellectual circulation of eschatological ideas would simply be ignored. This omission would not only narrow the border of the ancient, ${ }^{70}$ but also decrease the richness of spiritual hope and imagination.

\section{References}

Ambaum, Jan. 1991. "Hoffnung auf eine leere Hölle - Wiederherstellung aller Dinge? H.U. von Balthasars Konzept der Hoffnung auf das Heil." Internationale katholische Zeitschrift Communio 20: 33-46.

Anklesaria, Behramgore Tehmurasp. 1956. Zand-Ākāsìh: Iranian or Greater Bundahišn: Transliteration and Translation in English. Bombay: Published for the Rahnumae Mazdayasnan Sabha by its Honorary Secretary Dastur Framroze A. Bode.

Anrich, Gustav. 1902. "Clemens und Origenes als Begründer der Lehre vom Fegfeuer." In Theologische Abhandlungen: Eine Festgabe zum 17. Mai 1902 für Heinrich Julius Holtzmann, edited by Wilhelm Nowack, 97-102. Tübingen, Leipzig: J. C. B. Mohr.

Bailey, Harold W. 1971. Zoroastrian Problems in the Ninth Century Books. With a New Introduction by the Author. Ratanbai Katrak Lectures. Oxford: Clarendon Press.

Balthasar, Hans Urs von. 1987. Kleiner Diskurs über Die Hölle. Ostfildern: Schwabenverlag.

— 1988. "Apokatastasis. Gastvorlesung an der Theologischen Fakultät Trier am 18. April 1988.” Trierer Theologische Zeitschrift 97: 169-82.

67 In any case, it is useful to insist on the role of Aprahat (born around $270 \mathrm{CE}$ in Persia), who was perhaps a Zoroastrian before his conversion to Christianity. He probably knew not only Zoroastrian doctrines, but also Bardaisan's work, as Ramelli (Ramelli 2017, 393-96) fittingly argues.

68 From a methodological point of view, we must consider the strong disproportion between Mazdean and Christian original sources. In fact, considering that we can easily find sources, in a mass of hundreds of ancient Christian books, that clearly share a favour for the apokatastasis, the Zoroastrian Pahlavi texts cannot be considered as absolutely compact in their theological orientation. Thus, when we find one document that does not completely agree with the others, we cannot automatically infer that its orientations represents the whole Zoroastrianism of its age.

69 For a recent discussion of the Iranian elements in Bardaișan, see Ramelli (Ramelli 2017, 377-96).

70 Useful remarks on the cultural and inter-religious framework are suggested in the volumes edited by Kofsky and Ruzer (2016) and by Herman (2014), both with a pertinent general bibliography; see also Ramelli (2017) in her conclusions. Very important is the huge collection of papers dedicated to the cultural interaction between Mazdeans and Christians in Sasanian Iran by Gignoux (2014). 
1999. Kleiner Diskurs über die Hölle. Apokatastasis. Einsiedeln: Johannes.

Barr, James. 1962. Biblical Words for Time: Studies in Biblical Theology. London: SCM Press LTD.

Bartholomae, Christian. 1904. Altiranisches Wörterbuch. Strassburg: Karl J. Trübner.

Berti, Vittorio. 2009. Vita e Studi di Timoteo I, Patriarca cristiano di Baghdad. Studia Iranica: Cahier 41. Paris: Association pour l'avancement des études iraniennes.

Beulay, Robert. 1974. "Joseph Hazzâyâ.” In Dictionnaire de Spiritualité Ascétique et Mystique: Doctrine et Histoire, edited by Marcel Viller, 1341-9. Paris: Beauchesne.

Blochet, Edgard. 1898. "Le Livre intitulé l'Oulamâ-i Islâm." Revue de l'Histoire des Religions 38 (1): 23-29.

Boyce, Mary. 1975. A History of Zoroastrianism: The Early Period. Vol. 8. Handbuch der Orientalistik, Erste Abteilung, Nahe und der Mittlere Osten 1. Abschnitt. Leiden: Brill.

Bremmer, Jan. 2009. "Christian Hell: From the Apocalypse of Peter to the Apocalypse of Paul." Numen 56 (2-3): 298-325.

Brock, Sebastian. 1995. Isaak of Niniveh (Isaac the Syrian): “The Second Part"; Chapters IV-XLI. Corpus Scriptorum Christianorum Orientalium 555. Leuven: Peeters.

Bulliet, Richard. 1979. Conversion to Islam in the Medieval Period: An Essay in Quantitative History. Cambridge, MA: Harvard University Press.

Bundy, David. 1986. "The Book of the Holy Hierotheos and Manichaeism." Augustinianum 26 (1-2): 273-79.

Carile, Antonio. 1994. Materiali di Storia Bizantina. Bologna: Editrice lo Scarabeo.

Casartelli, Louis Charles. 1884. "La philosophie religieuse du Mazdéisme sous les Sassanides." Leuven: Maisonneuve frères et Ch. Leclerc.

- 1889. The Philosophy of the Mazdayasnian Religion Under the Sassanids. Translated by F. J. Jamasp Asa. Bombay: B. J. Karani.

Cereti, Carlo Giovanni. 1995a. "La figura del redentore futuro nei testi iranici zoroastriani: Aspetti dell'evoluzione di un mito." AION 55 (1): 33-81.

—. 1995b. "Padiriftan $i \overline{\text { Den }}$ and the Turn of the Millennium." East and West 45 (1/4): 321-27.

—. 1995c. The Zand i Wahman Yasn: A Zoroastrian Apocalypse. Rome Oriental Series 75. Roma: IsIAO.

—. 1996. The Zand i Wahman Yasn: A Zoroastrian Apocalypse. Rome: Istituto Italiano per il Medio ed Estremo Oriente.

Chialà, Sabino. 2002. Dall'ascesi eremitica alla misericordia infinita: Ricerche su Isacco di Ninive e la sua fortuna. Biblioteca della Rivista di Storia e Letteratura Religiosa 14. Florence: Leo S. Olschki.

- 2014. "Two Discourses of the 'Fifth Part' of Isaac the Syrian's Writings: Prolegomena for Apokatastasis?" In The Syriac Writers of Qatar in the Seventh Century, edited by Mario Kozah, Abdulrahim Abu-Husayn, Saif Shaheen Al-Murikhi, and Haya Al Thani, 123-31. Piscataway, NJ: Gorgias Press.

Choksy, Jamsheed K. 1987. "Zoroastrians in Muslim Iran: Selected Problems of Coexistence and Interaction During the Early Medieval Period." Iranian Studies 20 (1): 17-30. - 1997. Conflict and Cooperation: Zoroastrian Subalterns and Muslim Elites in Medieval Iranian Society. New York, NY: Columbia University Press. 
Christensen, Arthur. 1925. Le règne du roi Kawād I et le communisme mazdakite. Vol. 9. Det Kongelige Danske Videnskabernes Selskab historisk-filologiske Meddelelser 6. Copenhagen: B. Lunos.

Clemens, Titus Flavius. n.d. "The Stromata." In Fathers of Second Century: Hermas, Tatian, Athenagoras, Theophilus, and Clement of Alexandria, edited by Alexander Roberts, James Donaldson, and A. Cleveland Coxe, translated by William Wilson. Vol. 2. Ante-Nicene Fathers: Translations of the Writings of the Fathers Dawn to A.D. 325. Buffalo, NY: Eerdmans Publishing Company.

Cornélis, H. 1959. "Les fondements cosmologiques de l'eschatologie d'Origène." Revue des sciences philosophiques et théologiques 43 (1): 32-80.

Crone, Patricia. 1991. "Kavād's Heresy and Mazdak's Revolt." Iran 29: 21-42.

_. 1994. "Zoroastrian Communism." Comparative Studies in Society and History 36: 44762.

- 2012. The Nativist Prophets of Early Islamic Iran: Rural Revolt and Local Islamic Iran. Cambridge: Cambridge University Press.

Crousel, Henri. 1985. Origène. Le Sycomore: Chrétiens d'aujourd'hui 15. Paris: Lethielleux Culture et Vérité.

Cullmann, Oscar. 1962. Christus und die Zeit: Die urchristliche Zeit- und Geschichtsauffassung. Dritte durchgesehene Auflage. Zürich: EVZ-Verlag.

Cumont, Franz. 1931. "La fin du monde selon les mages occidentaux." Revue de l'histoire de religions 103 (1-3): 23-96.

Daniel, Elton. 1993. "Conversion ii: Of Iranians to Islam." In Encyclopcedia Iranica, edited by Ehsan Yarshatter, VI:229-32. Coffeehouse - Dārā. New York, NY: Routledge \& Kegan Paul.

Demichelis, Marco. 2018. Salvation and Hell in Classical Islamic Thought: Can Allah Save Us All? London, UK: Bloomsbury Academic.

Dhabhar, Bahmanji Nusserwanji. 1932. The Persian Rivayats of Hormazyar Framarz and Others: Their Version with Introduction and Notes. Bombay: K.R. Cama Oriental Institute.

Dhabhar, Bamanji Nasarvanji. 1949. Pahlavi Yasna and Visperad. Edited with an Introduction and a Glossary of Select Term. Pahlavi Texts Series 8. Bombay: The Shahnamah Press.

Durkin-Meisterernst, Desmond. 2004. Dictionary of Manichaean Middle-Persian and Parthian: Corpus Fontium Manichaeorum / Subsidia. Edited by Nocholas Sims-Williams. Vol. 3. Dictionary of Manichean Texts 1. Turnhout: Brepols.

Edsman, Carl-Martin. 1940. Le baptême avec le feu. Acta seminarii neotestamentici Upsaliensis 9. Leipzig, Uppsala: A. Lorentz / Lundequist.

- 1949. Ignis Divinus: Le feu comme moyen de rajeunissement et d'immortalité; Contes, légendes, mythes et rites. Lund: Gleerup.

El-Ṣaleh, Șoubhī. 1986. La vie future selon le Coran. Etudes musulmanes 13. Paris: J. Vrin.

Fernández, Samuel. 2017. "La fine e la Genesi: Rapporto tra escatologia e protologia nel De principiis di Origene." Adamantius 23: 167-79.

Frayer-Griggs, Daniel. 2016. Saved Through Fire: The Fiery Ordeal in New Testament Eschatology. Eugene, OR: Pickwick Publications.

Frendo, David. 1997. "The Religious Factor in Byzantine-Iranian Relations." Bulletin of the Asia Institute (N.S.) 11: 105-22. 
Frenschkowsi, Marco. 2004. "Parthica Apocalyptica: Mythologie und Militärwesen iranischer Völker in ihrer Rezeption durch die Offenbarung des Johannes." Jahrbuch für Antike und Christentum 47: 16-57.

Frothingham, Arthur Lincoln. 1886. Stephen Bar Sudaili, the Syrian Mystic, and the Book of Hierotheos. Leiden: Brill.

Früchtel, Ludwig, Otto Stählin, and Ursula Treu. 1979. Clemens Alexandrinus. Vol. 3. Die griechischen christlichen Schriftsteller, 52 (15), 17. Berlin: Akademie Verlag.

Gardner, Iain, Jason BeDuhn, and Paul Dilley, eds. 2018. The Chapters of the Wisdom of My Lord Mani. Nag Hammadi and Manichaean Studies 92. Leiden: Brill.

Geffcken, Johannes. 1902. Die Oracula Sibyllina. Vol. 8. Die griechischen christlichen Schriftsteller der ersten drei Jahrhunderte. Leipzig: J.C. Hinrichs'sche Buchhandlung.

Gignoux, Philippe. 1968. "L'enfer et le paradis d'après les sources pehlevies." Journal Asiatique 256 (2): 219-45.

. 1988. "L'apocalyptique iranienne est-elle vraiment la source d'autres apocalypses?" AAASH 31: 67-78.

. 1990. "Hexaéméron et Millénarisme: Quelques motifs de comparaison entre Mazdéisme et Judaïsme." In Irano-Judaica II: Studies Relating to Jewish Contacts with Persian Culture throughout the Ages, edited by Shaul Shaked and Amnon Netzer, 72-84. Jerusalem: Ben-Zvi Institute for the Study of Jewish Communities in the East.

- 1999. "L'apocalyptique iranienne est-elle vraiment ancienne? Notes critiques." Revue de l'histoire des religions 216 (2): 213-27.

. 2014. Mazdéens et chrétiens en terre d'Iran à l'époque sassanide. Edited by Matteo De Chiara and Enrico G. Raffaelli. Serie orientale Roma, nuova serie 3. Rome: Scienze e lettere.

Gignoux, Philippe, and Ahmad Tafazzoli. 1993. Anthologie de Zādspram: Èdition critique du texte pehlevi. Studia Iranica: Cahier. Paris: Association pour l'avancement des études iraniennes.

Gnoli, Gherardo. 1984. "Universalismo e Nazionalismo nell'Iran del III secolo." In Incontro di religioni in Asia tra il III e il X secolo d.C: Atti del Convegno Internazionale di studi storicoreligiosi (Venezia, 16-18 novembre 1981), edited by Lionello Lanciotti, Fondazione "Giorgio Cini", and Istituto italiano per il Medio ed Estremo Oriente, 31-54. Civiltà veneziana 39. Florence: L.S. Olschki.

Guillaumont, A. 1946. "Review of Le Baptême de Feu (Acta Seminarii Neotestamentici Upsaliensis Edenda Curavit A. Fridrichsen, IX), by Carl-Martin Edsman." Edited by CarlMartin Edsman. Revue de L'histoire Des Religions 131: 182-86. http://www.jstor.org/st able/23665570.

- 1958. Les Six Centuries de "Kephalaia Gnostica" d’Evagrie le Pontique. Vol. 1. Patrologia Orientalis 28. Paris: Firmin-Didot.

- 1962. Les Kephalaia Gnostica' d'Evagre le Pontique et l'histoire de l'Origénisme chez les Grecs et les Syriens. Patristica Sorbonensia 5. Paris: Éditions du Seuil.

Guillaumont, Antoine. 1969. "Justinien et L'eglise de Perse." Dumbarton Oaks Papers 23/24: 39-66. https://doi.org/10.2307/1291290.

. 1979. "Conférence de M. Antoine Guillaumont." Annuaires de l'École pratique des hautes études 88: 369-71. https://www.persee.fr/doc/ephe_0000-0002_1979_num_92_88_155 80. 
Heever, Gerhard van den. 1993. "In Purifying Fire: World-View and 2 Pet. 3:10." Neotestamentica 27: 107-18.

—. 2005a. "Making Mysteries: From the Untergang Der Mysterien to Imperial Mysteries - Social Discourse in Religion and the Study of Religion." Religion \& Theology 12 (3-4): 262-307.

- 2005b. "Novel and Mystery: Discourse, Myth, and Society." In Ancient Fiction: The Matrix of Early Christian and Jewish Narrative, edited by Jo-Ann A. Brant, Charles W. Hedrick, and Chris Shea, 89-114. Society of Biblical Literature Symposium Series 32. Atlanta, GA: Society of Biblical Literature.

Herman, Geoffrey, ed. 2014. Jews, Christians, and Zoroastrians: Religious Dynamics in a Sasanian Context. Judaism in Context 17. Piscataway, NJ: Gorgias Press.

Heschel, Susannah. 2008. The Aryan Jesus: Christian Theologians and the Bible in Nazi Germany. Princeton, NJ: Princeton University Press.

Himmelfarb, Martha. 1983. Tours of Hell: An Apocalyptic Form in Jewish and Christian Literature. Philadelphia, PA: University of Pennsylvania Press.

Hintze, Almut. 2019. "Defeating Death: Eschatology in Zoroastrianism, Judaism and Christianity." In Irano-Judaica VII: Studies Relating to Jewish Contacts with Persian Culture throughout the Ages, edited by Julia Rubanovich and Geoffrey Herman, 23-72. Jerusalem: The Ben-Zvi Institute for the Study of Jewish Communities in the East.

Hombergen, Daniël. 2001. The Second Origenist Controversy: A New Perspective on Cyril of Scythopolis' Monastic Biographies as Historical Sources for Sixth-Century Origenism. Studia Anselmiana 132. Rome: Centro studi S. Anselmo.

Hultgård, Anders. 2000. "La Chute de Satan: L'arrière-Plan Iranien d'un Logion de Jésus (Luc 10,18)." Revue d'Histoire et de Philosophie Religieuses 80 (1): 69-77.

Jaafari-Dehaghi, Mahmoud. 1998. Dādestān ī Dēnīg: Part I; Transcription, Translation and Commentary. Studia Iranica Cahier 20. Paris: Association pour l'Avancement des Études Iraniennes.

Jarry, Jacques. 1960. "Hérésies et factions à Constantinople du Ve au VIIe siècle." Syria 37 (3-4): 348-71. https://doi.org/10.3406/syria.1960.5492.

- 1968. Hérésies et factions dans l'empire byzantin: Du IVe au VIIe siècle. Cairo: Imprimerie de l'institut français d'archeologie orientale.

Jullien, Florence, and Marie-Josèphe Pierre-Beylot, eds. 2011. Monachismes d'Orient: Images, échanges, influences; Hommage à Antoine Guillaumont cinquantenaire de la chaire des "Christianisme orientaux", EPHE SR. Bibliothèque de l'Ecole des Hautes Etudes, Sciences Religieuses 148. Turnhout: Brepols.

Kavvadas, Nestor. 2013. "Jawsep Hazzāyā." In Christian Muslim Relations: A Bibliographical History, edited by David R. Thomas and Alex Mallett, 620-22. The History of ChristianMuslim Relations, 5 (1350-1500). Leiden: Brill.

- 2015. "The Apocalyptic Section of Joseph Hazzaya's on Divine Providence: A Reaction to Islamisation." Parole de L'Orient 40: 243-49.

- 2016. Joseph Hazzaya: On Providence. Texts and Studies in Eastern Christianity 8. Leiden: Brill.

Kellens, Jean. 2000. "L'ellipse du temps." In Anusantatyai: Festschrift für Johanna Narten zum 70. Geburtstag, edited by Almut Hintze and Eva Tichy, 127-31. Münchener Studien zur Sprachwissenschaft, Beiheft 19, Neue Folge. Dettelbach: J.H. Röll. 
—. 2009. "Structure de L'espace-Temps Dans Le Mazdéisme Ancien." In The Past in the Past: Concepts of Past Reality in Ancient Near Eastern and Early Greek Thought, edited by Hans M. Barstad and Pierre Briant, 37-45. Serie B-Skrifter, vol. 130. Oslo: Novus Press: Institute for Comparative Research in Human Culture.

Kellens, Jean, and Eric Pirart, eds. 1988. Les Textes vieil-avestiques. Vol. 1. Wiesbaden: L. Reichert.

, eds. 1990. Les Textes vieil-avestiques. Vol. 2. Wiesbaden: L. Reichert.

Kestenberg Amighi, Janet. 1990. The Zoroastrians of Iran: Conversion, Assimilation, or Persistence. Illustrated. AMS Studies in Anthropology 3. New York, NY: AMS Press.

Klíma, Otakar. 1957. Mazdak: Geschichte einer sozialen Bewegung im Sassanidischen Persien. Prague: Československé Akademie věd.

—. 1977. Beiträge zur Geschichte des Mazdakismus. Dissertationes Orientales 37. Prague: Verlag der Tschechoslowakischen Akademie der Wissenschaften.

Kofsky, Arieh, and Serge Ruzer. 2016. Reshaping Identities in Late Antique Syria-Mesopotamia: Christian and Jewish Hermeneutics and Narrative Strategies. Judaism in Context 19. Piscataway, NJ: Gorgias Press.

Kuehn, Sara. 2014. "The Dragon Fighter: The Influence of Zoroastrian Ideas on JudaeoChristian and Islamic Iconography." ARAM 26 (1\&2): 59-92.

Lettieri, Gaetano. 1996. Deus patiens: L'essenza cristologica dello gnosticismo. Rome: G. Lettieri.

- 2005. "Il nus mistico: Il superamento origeniano dello gnosticismo nel 'Commento a Giovanni'." In Il commento a Giovanni di Origene: Il testo e i suoi contesti: atti dell'VIII convegno di studi del Gruppo italiano di ricerca su Origene e la tradizione Alessandrina (Roma, 28-30 settembre 2004), edited by Emanuela Prinzivalli, 177-275. Biblioteca di Adamantius 3. Villa Verucchio (Rimini): P. G. Pazzini.

- 2011. "Reductio ad unum: Dialettica cristologica e retractatio dello gnosticismo valentiniano nel Commento a Matteo di Origene." In Il Commento a Matteo di Origene: atti del $X$ Convegno di studi del Gruppo italiano di ricerca su Origene e la tradizione Alessandrina (Napoli, 24-26 settembre 2008), edited by Teresa Piscitelli, 237-87. Brescia: Morcelliana.

—. 2017a. "Dies una: L'allegoria di «coelum et terra in Principio» ricapitolazione del sistema mistico-speculativo di Origene." Adamantius 23: 45-84.

— 2017b. "Eriugena e Origene: Una libertà assoluta." In Libertà e determinismo: Riflessioni medievali, edited by Marialucrezia Leone and Luisa Valente, 15-84. Flumen Sapientiae 4. Canterano (Rome): Aracne.

Lienhard, Joseph T., trans. 1996. Homilies on Luke: Fragments on Luke. The Fathers of the Church 94. Washington, DC: Catholic University of America Press.

Lincoln, Bruce. 1985. "Notes Toward a Theory of Religion and Revolution." In Religion, Rebellion, Revolution: An Interdisciplinary and Cross-Cultural Collection of Essays, edited by Bruce Lincoln, 266-99. Basingstoke, Hampshire: Palgrave Macmillan.

— . 2007a. "Epilogue." In Ancient Religions, edited by Sarah Iles Johnston, 241-51. Cambridge, MA: Belknap Press of Harvard University Press.

- 2007b. Religion, Empire, and Torture: The Case of Achaemenian Persia, with a Postscript on Abu Ghraib. Chicago, IL: University of Chicago Press.

L'Orange, Hans Peter. 1953. Studies on the Iconography of Cosmic Kingship in the Ancient World. Oslo: H. Aschehoug.

MacKenzie, David Neil. 1971. A Concise Pahlavi Dictionary. London, UK: Oxford University Press. 
Mak, Bill M. 2016. "Astral Science of the East Syriac Christians in China During the Late First Millennium AD." Mediterranean Archaeology and Archaeometry 16 (4): 87-92.

Malalas, Johannes. 1831. Ioannis Malalae Chronographia ex recensione Ludvici Dindorfii. Bonnae: Impensis Ed. Weberi.

Malandra, William W., and Pallan R. Ichaporia. 2013. The Pahlavi Yasna of the Gāthās and Yasna Haptanhāiti. Wiesbaden: Dr. Ludwig Reichert Verlag.

Marsh, Fred S. 1927. The Book Which Is Called the Book of the Holy Hierotheos, with Extracts from the Prolegomena and Commentary of Theodosios of Antioch and from the "Book of Excerpts" and Other Works of Gregory Bar-Hebrceus. Translated by Fred S. Marsh. London, UK: Williams and Norgate.

Martindale, John Robert. 1980. The Prosopography of the Later Roman Empire. Vol. 2. Cambridge: Cambridge University Press.

Menasce, Jean de. 1945. Škand-gumānīk vičār: La solution décisive des doutes; Texte pazandpehlevi. Collectanea Friburgensia 30. Fribourg en Suisse: Librairie de l'Université.

— ed. 1973. Le troisième livre du Denkart: Travaux de l'Institut d'Études iraniennes de l'Université de Paris III. 5. Bibliothèque des oeuvres classiques persanes 4. Paris: Klincksieck.

Migne, Jacques-Paul. 1862. Patrologiae Cursus Completus [...]. Series Graeca Prior: Patrologiae Graecae Tomus XIII; Origenis Opera Omnia opera et studio DD; Caroli et Caroli Vincentii Delarue; Tomus Tertius. Paris: J.-P. Migne Editor.

Minov, Sergey. 2013. "Syriac Christian Identity in Late Sasanian Mesopotamia: The Cave of Treasures in Context." Jerusalem: The Hebrew University of Jerusalem.

Molenberg, Corrie. 2017. "The Silence of the Sources: The Sixth Century and East-Syrian 'Antiochene' Exegesis." In The Sixth Century: End or Beginning?, edited by Pauline Allen and Elisabeth Jeffrey, 145-62. Byzantina Australiensia 10. Leiden: Brill.

Müller, Carl. 1851. Fragmenta Historicorum Graecorum: Collegit, disposuit notis et prolegomenis illustravit; Carolus Mullerus. Vol. Quartum. Paris: Edtore Ambrosio Firmin Didot.

Müller, Gotthold. 1958. "Origenes und die Apokatastasis." Theologische Zeitschrift 14: 174-90.

Nicephorus. 1990. Short History. Translated by Cyril A. Mango. Dumbarton Oaks Texts 10. Washington, DC: Dumbarton Oaks.

Olhausen, Justus, and Jules Mohl. 1829. Fragmens relatifs à la religion de Zoroastre, extraits des manuscrits persans de la Bibliothèque du Roi. Paris: Imprimerie Royale.

Orelli, Conrad von. 1871. Die hebräischen Synonyma der Zeit und Ewigkeit genetisch und sprachvergleichend. Leipzig: Lorentz.

Panaino, Antonio. 2004a. "Astral Characters of Kingship in the Sasanian and Byzantine Worlds." In La Persia E Bisanzio: Convegno Internazionale (Roma, 14 - 18 Ottobre 2002), edited by Antonio Carile, 555-94. Atti Dei Convegni Lincei 201. Rome: Accademia nazionale dei Lincei; Istituto Italiano per il Medio e l'Estremo Oriente. . 2004b. "La Chiesa di Persia e l'Impero Sasanide: Conflitto e Integrazione." In Cristianità d'Occidente e cristianità d'Oriente (secoli VI-XI): 24-30 aprile 2003, edited by Centro italiano di studi sull'alto Medioevo. Settimana di studio, 765-863. Settimane di studio della Fondazione Centro italiano di studi sull'alto Medioevo 51. Spoleto: Fondazione Centro italiano di studi sull'alto Medioevo.

. 2005. "Ahreman's End Between Theology and Philosophy." HAMAZOR 37 (1): 92-94. . 2008. "L'aldilà zoroastriano e quello dantesco: Appunti per una riflessione comparativa e tipologica su forme e motivi ricorrenti nei viaggi ultraterreni." In Dante e la fab- 
brica della Commedia: Atti del Convegno Internazionale di Studi, Ravenna 14-16 settembre 2006, edited by Alfredo Cottignoli, Donatino Domini, and Giorgio Gruppioni, 171-87. Ravenna: Longo Editore.

- 2009a. "Ahreman and Narcissus." In Literarische Stoffe und ihre Gestaltung in mitteliranischer Zeit: Colloquium anlässlich des 70. Geburtstags von Werner Sundermann, edited by Desmond Durkin-Meisterernst, Christiane Reck, and Dieter Weber, 201-9. Beiträge zur Iranistik 31. Wiesbaden: Reichelt Verlag.

- 2009b. "Il duplice volto del protocollo aggiuntivo sulle minoranze religiose nella 'Pace dei 50 anni'." Bizantinistica: Rivista di Studi Bizantini e Slavi 11: 273-99.

- 2009c. "The 'Mental' Dimension of Evil: Psychoanalytic Remarks on the Image and Behaviour of Ahreman in the Framework of Zoroastrian Cosmology." In Geist, Gehirn, Verhalten: Sigmund Freud und die modernen Wissenschaften, edited by Patrizia GiampieriDeutsch, 143-58. Würzburg: Königshausen \& Neumann.

- 2010. "Secondo l'uso antico: A proposito del Calendario comune adottato nel XIII punto del Trattato di Pace del 561 tra Sasanidi e Romani." Bizantinistica: Rivista di Studi Bizantini e Slavi 12: 115-48.

. 2013a. "Mortality and Immortality: Yama's / Yima's Choice and the Primordial Incest; Mythologica Indo-Iranica, I." In Disputationes Iranologicae Vindobonensis. II, edited by Velizar Sadovski and Antonio Panaino, 47-221. Sitzungsberichte / Österreichische Akademie der Wissenschaften, Philosophisch-Historische Klasse 845. Vienna: Verlag der Österreichischen Akademie der Wissenschaften.

- 2013b. "The 'Gift' of the 'Givers'." In Gifts to a Magus: Indo-Iranian Studies Honoring Firoze Kotwal, edited by Jamsheed K. Choksy and Jennifer Dubeansky, 137-45. Toronto Studies in Religion 32. New York, NY: Peter Lang.

- 2014. "Christians and Zoroastrians in the Fifty-Years Peace Treaty." Nāme-Ye Irān-E Bāstān. The International Journal of Ancient Iranian Studies 12: 67-90.

—. 2015a. "Una stessa divinità? Cristiani e Mazdei dinanzi alla necessità di invocare un dio comune." In Ex pluribus unum: Studi in onore di Giulia Sfameni Gasparro, edited by Concetta Giuffrè Scibona and Attilio Mastrocinque, 415-20. Rome: Edizioni Quasar.

—. 2015b. "Yima ed il rifiuto della daênâ-: Ovvero dell'incestualità, della beatitudine e della morte tra ambigui ostacoli e seducenti trasparenze." In Démons iraniens: Actes du colloque international organisé à l'Université de Liège les 5 et 6 février 2009 à l'occasion des 65 ans de Jean Kellens, edited by Philippe Swennen, 97-123. Collection Religions 4. Liège: Presses Universitaires de Liège.

- 2016. "6666 or the Figure of Ahreman's Invasion: A Note About Wizīdagīhā by Zādspram 28,2." Studia Iranica 45 (2): 165-96.

_. 2017a. "Astrologi cristiani alle corti Sasanide e Cinese." Bizantinistica 18: 149-65. . 2017b. "Avestan Aiiara- and Asniia- (Y. 1,17; 2,17, Etc.)." Indo-Iranian Journal 60 (4): 303-30. https://doi.org/10.1163/15728536-06003003.

- 2017c. "La 'misericordia' di Ohrmazd ed il perdono dei dannati secondo la trattatistica zoroastriana tardo-antica e medievale." Bizantinistica 17: 27-45.

. 2017d. "Liturgies and Calendars in the Politico-Religious History of Pre-Achaemenian and Achaemenian Iran." In Persian Religion in the Achaemenid Period: La Religion Perse à L'époque Achéménide, edited by Wouter Henkelman and Ćeline Redard, 69-95. Classica et Orientalia 16. Wiesbaden: Harrassowitz Verlag. 
. 2017e. "Multilingualism and Empires: Byzantium and Sasanian Persia." In Zur Lichten Heimat Studien Zu Manichäismus, Iranistik Und Zentralasienkunde Im Gedenken an Werner Sundermann, edited by Team "Turfanforschung“, 491-502. Iranica 25. Wiesbaden: Harrassowitz.

. 2017f. "The End of Time and the 'Laws of Zoroaster': A Zoroastrian Doctrine in the Manichaean Reception." In In Limine. Esplorazioni Attorno All'idea Di Confine, edited by Francesco Calzolaio, Erika Petrocchi, Marco Valisano, and Alessia Zubani, 61-68. Studi E Ricerche 9. Venice: Edizioni Ca' Foscari.

- 2017g. "Vecchie e Nuove Considerazioni sul Millenarismo iranico-mesopotamico ed il Chiliasmo giudaico-cristiano." In Studi Iranici Ravennati II, edited by Antonio Panaino and Andrea Piras, 183-229. Studia Indo-Iranica et Orientalia: Series Lazur 14. Milan: Mimesis.

- 2018. "The 'Trepidation' of the Sun, the 57 Years of the Resurrection and the Late Mazdean Speculations on the Apocalypse." Studia Iranica 47 (1): 7-50.

- Forthcoming. "On the Mazdean Animal and Symbolic Sacrifices; Their Problems, Timing and Restrictions." In Aux Sources Des Liturgies Indo-Iraniennes, edited by Céline Redard, Joan Joseph Ferrer-Losilla, Hamid Moein, and Swennen. Liège: Presses Universitaires de Liège.

Payne, Richard E. 2015. A State of Mixture: Christians, Zoroastrians, and Iranian Political Culture in Late Antiquity. Berkeley, CA: University of California Press.

Pākzād, Faẓl Allāh, and Markaz-i Dā’irat al-Ma'ārif-i Buzurg-i Islāmī (Iran), eds. 2005. Bundahišn: Zoroastische Kosmogonie und Kosmologie; Band I. Kritische Edition. Ancient Iranian Studies Series 2. Tehran: Centre for the Great Islamic Encyclopaedia.

Pinggéra, Karl. 2002. "Gregor Bar Hebraeus und die 'Theologie der Hoffnung' des Joseph Hazzaya: Anmerkungen zur Eschatologie im Ethikon und im Buch der Taube." In Syriaca: Zur Geschichte, Theologie, Liturgie und Gegenwartslage der syrischen Kirchen, edited by Martin Tamcke, 225-41. Studien zur orientalischen Kirchengeschichte 17. Münster: LIT Verlag.

Pingree, David. 1976. Dorothei Sidonii Carmen Astrologicum. Leipzig: Teubner. - 1989. "Classical and Byzantine Astrology in Sassanian Persia." Dumbarton Oaks Papers 44: 227-39.

Piras, Andrea. 2000. Hādōxt Nask 2: Il racconto zoroastriano della sorte dell'anima; Edizione critica del testo avestico e pahlavi, traduzione e commento. Serie orientale Roma 88. Rome: Istituto italiano per l'Africa e l'Oriente.

Ramelli, Ilaria. 2009. Bardaisan of Edessa: A Reassessment of the Evidence and a New Interpretation; Also in the Light of Origen and the Original Fragments from de India. Piscataway, NJ: Gorgias Press.

—. 2013a. "L'apocatastasi in Origene: Un confronto con l'apocatastasi storica." Chaos e Kosmos 13: 1-15.

- 2013b. The Christian Doctrine of Apokatastasis: A Critical Assessment from the New Testament to Eriugena. Supplements to Vigiliae Christianae 120. Leiden: Brill.

- 2017. "Christian Apokatastasis and Zoroastrian Frashegird: The Birth of Eschatological Universalism." Religion and Theology 24 (3-4): 350-406.

Reck, Christiane. 2004. Gesegnet sei dieser Tag: Manichäische Festtagshymnen; Edition der mittelpersischen und parthischen Sonntags-, Montags- und Bemahymnen. Berliner Turfantexte 22. Turnhout: Brepols. 
Reinink, Gerrit J. 1999a. "Babai the Great's Life of George and the Propagation of Doctrine in the Late Sasanian Empire." In Portraits of Spiritual Authority: Religious Power in Early Christianity, Byzantium, and the Christian Orient, edited by Jan Willem Drijvers and John W. Watt, 171-95. Religions in the Graeco-Roman World 137. Leiden: Brill.

. 1999b. "Origenism in Thirteenth-Century Northern Iraq." In After Bardaisan: Studies on Continuity and Change in Syriac Christianity in Honour of Professor Han J.W. Drijvers, edited by Gerrit J. Reinink and Alexander Cornelis Klugkist, 237-52. Orientalia Lovaniensia Analecta 89. Leuven: U. Peeters en Departement Oosterse Studies.

— 2010. "The East Syrian Monk Simon the Persecuted and His Book of Chapters." In Gotteserlebnis und Gotteslehre: Christliche und islamische Mystik im Orient, edited by Martin Tamcke, 38:61-70. Göttinger Orientforschungen. Reihe 1, Syriaca. Wiesbaden: Harrassowitz Verlag.

Sasse, Hermann. 1933. "Aî́v, alẃvoc." In Theologisches Wörterbuch Zum Neuen Testament, Erster Band: A-- $\Gamma$, edited by Gerhard Kittel, 197-209. Stuttgart: W. Kolhammer.

Schaeder, H. H. 1930. "Perser: III. Parsismus und Judentum." In Die Religion in Geschichte und Gegenwart, edited by Hermann Gunkel and Leopold Zscharnach, 2nd ed., 4: Mi R:1085-7. Tübingen: Mohr.

Scher, Addai. 1909. "Joseph Ḥazzâyâ, écrivain syriaque du VIIIe siècle.” Comptes rendus des séances de l'Académie des Inscriptions et Belles-Lettres 53 (4): 300-307.

—. 1910. "Joseph Hazzâyâ, écrivain syriaque du VIIIe siècle." Rivista degli Studi Orientali 3: 45-63.

Shaked, Shaul. 1970. "Eschatology and the Goal of the Religious Life in Sasanian Zoroastrianism." In Types of Redemption, edited by Raphael Judah Zwi Werblowsky and Claas Juoco Bleeker, 223-30. Leiden: Brill.

—. 2002. "Hadith V. As Influences by Iranian Ideas and Practices." In Encyclopaecedia Iranica, edited by Ehsan Yarshater, XI, Fasc. 5:453-57. New York, NY.

Shaki, Mansour. 1978. "The Social Doctrine of Mazdak in the Light of Middle Persian Evidence." Archív Orientální 46: 289-306.

. 1986. "Dūzak.." In Encyclopcedia Iranica, edited by Ehsan Yarshater, VII, Fasc. 6:61315. London: Routledge.

— 1999. "Falsafa I. Pre-Islamic Philosophy." In Encyclopcedia Iranica, edited by Ehsan Yarshater, 9:176-82. New York, NY.

Simmons, Michael Bland. 2015. Universal Salvation in Late Antiquity: Porphyry of Tyre and the Pagan-Christian Debate. Oxford Studies in Late Antiquity. Oxford: Oxford University Press.

Stern, Sacha. 2007. Time and Process in Ancient Judaism. The Littman Library of Jewish Civilization. Oxford: Littman Library of Jewish Civilization.

Stickel, Farida. 2007. "Zwischen Anpassung und offenem Widerstand: Die Zoroastrier unter islamischer Herrschaft bis zum 4./10. Jahrhundert." M.A. Thesis.

Sundermann, Werner. 1977. "Mazdak und die mazdakitischen Volksaufstände." Das Altertum 4: 245-49.

Tardieu, Michel. 1985. "L'Ardā Virāz Nāmāg et l'eschatologie grecque." Studia Iranica 14 (1): 17-26.

Unvala, Manockji Rustamji. 1922. Dārāb Hormazyār's Rivāyat. Vol. 2. Bombay: British India Press. 
Vööbus, Arthur. 1965. History of the School of Nisibis. Corpus Scriptorum Christianorum Orientalium 266. Leuven: Peeters.

Vullers, Johann August. 1831. Fragmente über die Religion des Zoroaster, aus dem Persischen übersetzt und mit einem ausführlichen Commentar versehen, nebst dem Leben des Ferdusi aus Dauletschah's Biographieen der Dichter: Mit einem Vorworte von Prof. [Josef Hieronymus] Windischmann. Bonn: T. Habicht.

Walker, Joel Thomas. 2006. The Legend of Mar Qardagh: Narrative and Christian Heroism in Late Antique Iraq. The Transformation of the Classical Heritage 40. Berkeley: University of California Press.

Ware, Kallistos. 2005. The Inner Kingdom. Crestwood, NY: St Vladimir's Seminary Press.

West, Edward William. 1885. Pahlavi Texts. Vol. 3. Sacred Books of the East 24. Oxford: Oxford University Press.

Widengren, Geo. 1984. "The Nestorian Church in Sasanian and Early Post-Sasanian Iran." In Incontro di Religioni in Asia tra il III e il X secolo d.C, edited by Lionello Lanciotti and Istituto italiano per il Medio ed Estremo Oriente, 1-30. Civiltà veneziana 39. Florence: L.S. Olschki.

Yarshater, Ehsan. 1983. "Mazdakism." In The Cambridge History of Iran: Seleucid Parthian, edited by Ehsan Yarshater, 2:991-1024. The Cambridge History of Iran, III. Cambridge: Cambridge University Press. https://doi.org/10.1017/CHOL9780521246934.013.

Zaehner, Richard Charles. 1955. Zurvan: A Zoroastrian Dilemma. Oxford: Clarendon Press.

. 1956. The Teachings of the Magi: A Compendium of Zoroastrian Beliefs. London, UK; New York, NY: Allen \& Unwin, Macmillan. 